Prepared in cooperation with the U.S. Fish and Wildlife Service

\title{
Geomorphic Classification of the Lower Platte River, Nebraska
}
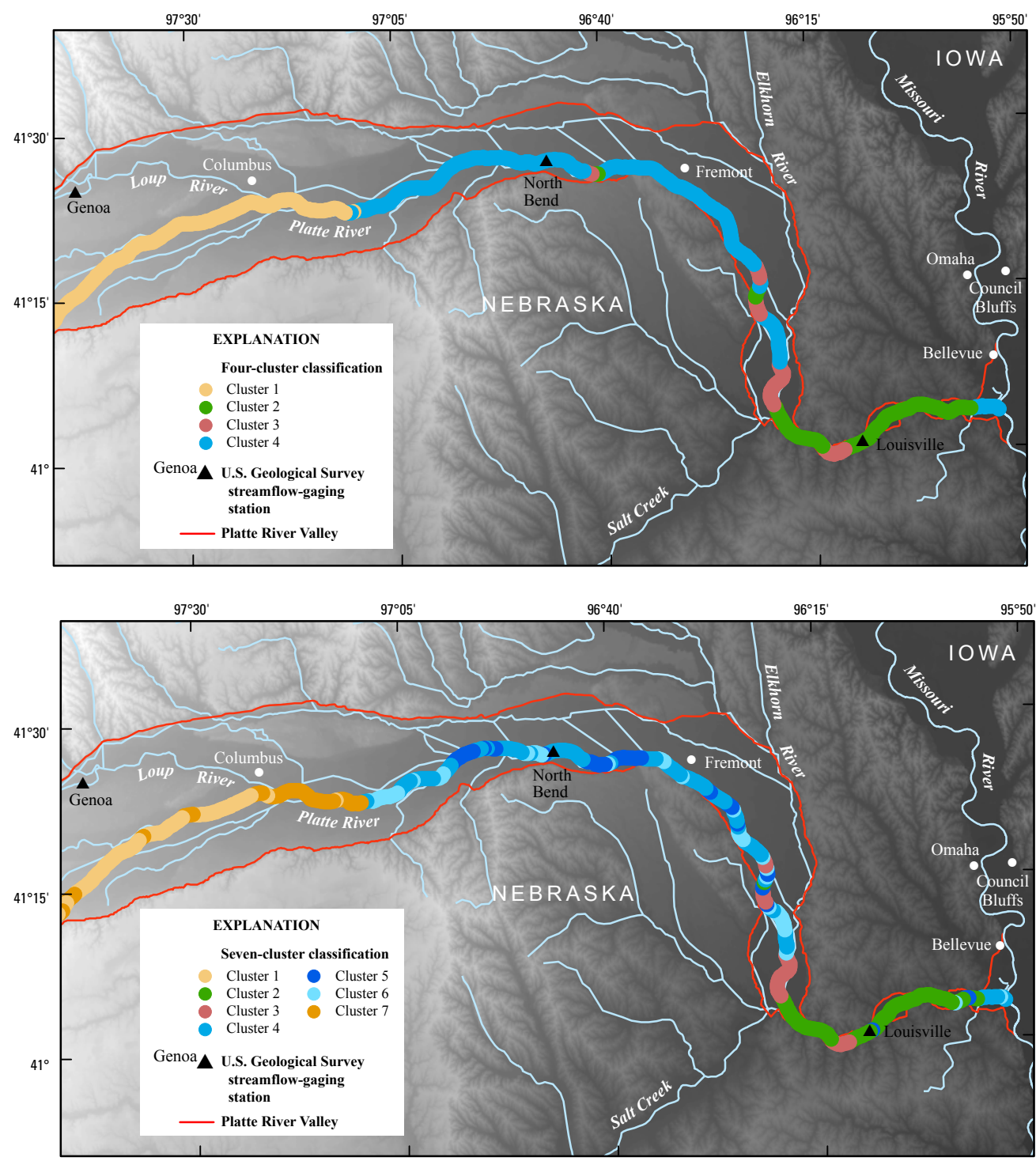

Scientific Investigations Report 2009-5198 
Cover. Examples of four- and seven-cluster classifications on the Lower Platte River. 


\section{Geomorphic Classification of the Lower Platte River, Nebraska}

By Caroline M. Elliott, Brittany L. Huhmann, and Robert B. Jacobson

Prepared in cooperation with the U.S. Fish and Wildlife Service

Scientific Investigations Report 2009-5198 


\title{
U.S. Department of the Interior \\ KEN SALAZAR, Secretary
}

\author{
U.S. Geological Survey \\ Suzette M. Kimball, Acting Director
}

U.S. Geological Survey, Reston, Virginia: 2009

For more information on the USGS - the Federal source for science about the Earth, its natural and living resources, natural hazards, and the environment, visit http://www.usgs.gov or call 1-888-ASK-USGS

For an overview of USGS information products, including maps, imagery, and publications, visit http://www.usgs.gov/pubprod

To order this and other USGS information products, visit http://store.usgs.gov

Any use of trade, product, or firm names is for descriptive purposes only and does not imply endorsement by the U.S. Government.

Although this report is in the public domain, permission must be secured from the individual copyright owners to reproduce any copyrighted materials contained within this report.

Suggested citation:

Elliott, C.M., Huhmann, B.L., Jacobson, R.B., 2009, Geomorphic Classification of the Lower Platte River, Nebraska: U.S. Geological Survey Scientific Investigations Report 2009-5198, 29 p. 


\section{Contents}

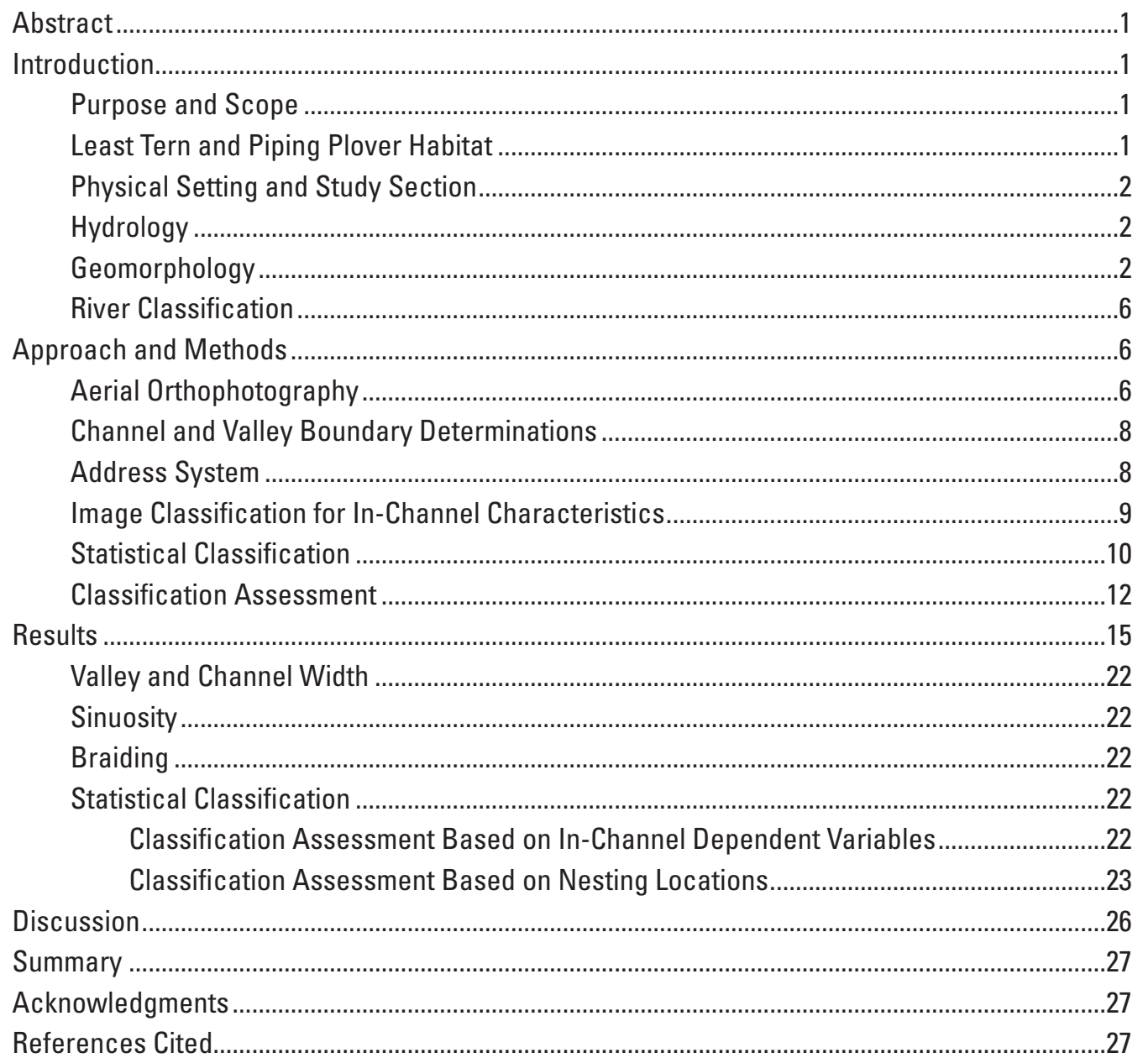

\section{Figures}

1. Map showing the Platte River Basin and the Lower Platte River study area ....................3

2-3. Graphs showing-

2. Discharge for the Lower Platte River and tributaries.................................................

3. Locations and discharges on the Lower Platte River for 2006 National Aerial Imagery Program photographs used in this study at the Grand Island, North Bend, and Louisville gages on the Platte River, Nebraska.

4-6. Maps showing-

4. Address system created for data collection based on the channel centerline..........8

5. Selection of training samples for the woody vegetation category of the computerized classification.

6. Comparison of National Aerial Imagery Program (NAIP) photography, manual classification, and computerized classification for a 2-kilometer representative section of the Platte River. 
7-8. Graphs showing-

7. Platte River geomorphic characteristics including valley width, channel width, sinuosity, sandbar count, braiding index, and percent of channel composition

8. Principal components analysis of selected variables...............................................14

9-10. Scatterplots showing -

9. Selected, non-transformed classification variables .................................................15

10. The reduced set of selected classification variables ................................................16

11. Hierarchical cluster dendrogram of the reduced dataset............................................16

12-16. Graphs showing-

12. Changes in sum of square differences within and among clusters as number of clusters changes.

13. Clustering results from the K-means procedure for four clusters ............................17

14. Clustering results from the $\mathrm{K}$-means procedure for seven clusters..........................18

15. Canonical scores for the four-cluster classification .............................................18

16. Canonical scores for the seven-cluster classification .............................................19

17. Maps showing examples of four- and seven-cluster classifications on the Lower Platte River

18-19. Box plots showing-

18. Response variables by four- and seven-cluster classifications

19. Percent channel type from supervised imagery classification by reach for the Lower Platte River

\section{Tables}

1. Dates and river discharges for 2006 digital photography .................................................

2. Comparison of automated and manual classifications of a 2-kilometer reach of the Platte River

3. Variable names, abbreviations, and definitions

4. Result of jackknife validation of discriminant function classification of fourand seven-cluster classifications

5. Names and interpreted physical significance of clustered classes .............................20

6. Lower Platte River geomorphic attributes summarized by hydrologic segment.............23

7. Tern and Plover nest locations and selectivity coefficients by cluster type .25 


\section{Conversion Factors and Datum}

\begin{tabular}{lcl}
\hline \multicolumn{1}{c}{ Multiply } & \multicolumn{1}{c}{ By } & \multicolumn{1}{c}{ To obtain } \\
\hline meter $(\mathrm{m})$ & Length & \\
kilometer $(\mathrm{km})$ & 3.281 & foot $(\mathrm{ft})$ \\
kilometer $(\mathrm{km})$ & 0.6214 & mile $(\mathrm{mi})$ \\
meter $(\mathrm{m})$ & 0.5400 & mile, nautical $(\mathrm{nmi})$ \\
\hline & 1.094 & yard $(\mathrm{yd})$ \\
\hline cubic meter $\left(\mathrm{m}^{3}\right)$ & Area & \\
cubic kilometer $\left(\mathrm{km}^{3}\right)$ & 1.308 & cubic yard $\left(\mathrm{yd}^{3}\right)$ \\
cubic meter $\left(\mathrm{m}^{3}\right)$ & 0.2399 & cubic mile $\left(\mathrm{mi}^{3}\right)$ \\
square meter $\left(\mathrm{m}^{2}\right)$ & 0.0008107 & acre-foot $(\mathrm{acre}-\mathrm{ft})$ \\
\hline & 10.76 & square foot $\left(\mathrm{ft}^{2}\right)$ \\
\hline cubic meter per second $\left(\mathrm{m}^{3} / \mathrm{s}\right)$ & Flow rate & \\
cubic meter per second $\left(\mathrm{m}^{3} / \mathrm{s}\right)$ & 70.07 & acre-foot per day $(\mathrm{acre}-\mathrm{ft} / \mathrm{d})$ \\
\hline
\end{tabular}

Horizontal coordinate information is referenced to the North American Datum of 1983 (NAD 83). 



\title{
Geomorphic Classification of the Lower Platte River, Nebraska
}

\author{
By Caroline M. Elliott, Brittany L. Huhmann, and Robert B. Jacobson
}

\begin{abstract}
Geomorphic attributes were collected from natural color aerial orthophotography to develop a multiscale classification for the downstream-most 220 kilometers of the Platte River in eastern Nebraska. The intent of this classification is to define discrete reaches that have geomorphic characteristics favorable to endangered interior least terns (Sternula antillarum) and threatened piping plovers (Charadrius melodus) who use riverine sandbars for nesting habitat. Annual to daily fluctuations in discharge present a challenge to characterizing emergent sandbar habitat directly from existing aerial orthophotography for the Platte River. Therefore, this classification is based on geomorphic measures that are relatively insensitive to prevailing river discharge but may be physically related to emergent sandbar locations. Such features include valley width, channel width, and sinuosity. The results provide fourcluster and seven-cluster classifications for the Lower Platte River based on naturally occurring, statistically determined clusters of features. The classification was validated using tern and plover nest data for 2006-08. Forty-nine percent of the nest locations fell within the same class type in the four-cluster classification, which represented 18 percent of the study area. This class is found primarily in the Eastern Platte River Gorge, downstream from Salt Creek and upstream from the junction of the Platte River with the Missouri River.
\end{abstract}

\section{Introduction}

The 170 kilometers $(\mathrm{km})$ of the Platte River from the Loup River junction to its mouth (the Lower Platte River) have historically been nesting areas for the endangered interior least tern (Sternula antillarum) and threatened piping plover (Charadrius melodus) (Lingle, 1993; Lott, 2006). The riverine habitats these shore and seabirds utilize for nesting, foraging, and rearing on the Lower Platte River include sparsely vegetated channel sandbars, sand and gravel beaches on islands, temporary pools on sandbars and islands, and river shorelines (Ziewitz and others, 1992; Lingle, 1993; Kirsch, 1996). Successful tern and plover nesting has been historically documented on ephemeral sandbars in the Lower Platte River and adjacent sandpits, and some level of monitoring has occurred since the species were listed in 1985 and 1986 (U.S. Fish and Wildlife Service, 2006; Brown and Jorgenson, 2008). Tern and plover nesting on the Platte River is denser downstream from the junction with the Loup River, a relatively undeveloped sand-bedded tributary, compared to upstream Platte River reaches (Ziewitz and others, 1992; Joel Jorgenson, unpub. data, Nebraska Game and Parks Commission, 2009).

A river classification can serve as a useful template to guide habitat management and to aid design of monitoring programs. For instance, a geomorphic river classification may define discrete reaches with processes necessary for the maintenance of nesting habitats. One potential application of the classification presented here would be to enable Federal, State, and local resource managers to integrate regional conservation planning for Platte River resources by grouping reaches with similar physical characteristics.

\section{Purpose and Scope}

This report presents a longitudinal, multivariate classification for the Lower Platte River based on remotely-sensed geomorphic characteristics. The intent of this classification was to identify reaches of the Platte River with similar geomorphic characteristics and physical processes. The classification will provide a landscape-scale perspective on Platte River physical habitats that may aid in determining reach-scale characteristics related to tern and plover nesting.

\section{Least Tern and Piping Plover Habitat}

Interior least terns and piping plovers nest on emergent sandbar habitat on the Platte River and sandpits in the Platte River Valley (Kirsch, 1996; Lott, 2006). On the Platte River, nesting occurs on bare to sparsely vegetated sandbars with generally less than 25 percent vegetation (Kirsch, 1996). Terns and plovers tend to nest on the highest elevation unvegetated areas of sandbars on the Platte River (Sidle and others, 1992; Ziewitz and others, 1992). Terns and plovers have been found to nest on sites with a wide active channel and large mid-channel sandbars on the Lower and Central Platte River (Ziewitz and others, 1992). Platte River riverine environments are 
important for foraging and congregation for terns and plovers that nest on off-river sandpits (Lingle, 1993).

To create and maintain bare sandbars for nesting, periodic high flows are necessary to scour vegetation on existing bars and create new bars (Sidle and others, 1992; Parham, 2007). The timing of high flows is crucial to nesting success. High flows that occur too late in the nesting season may result in high mortality, and sustained high flows that cover sandbars and last throughout the nesting season result in habitat inundation (Sidle and others, 1992). High flows that recede early in the season should not affect nesting, and high flows that occur late in the nesting season will not adversely affect many nests when chicks are mobile and can usually move to higher ground (Sidle and others, 1992).

\section{Physical Setting and Study Section}

We examined the geomorphic features of the downstream-most $220 \mathrm{~km}$ of the Platte River in Nebraska to develop a geomorphically based channel classification (fig. 1). The Lower Platte River is designated as the segment downstream from the Loup River junction near Columbus, Nebraska. We also included fifty $\mathrm{km}$ of the Platte River upstream from the Loup River junction in the analysis; while not conventionally part of the Lower Platte River, this section provided a comparative example of a hydrologically distinct segment of the Platte River.

The Platte River generally is a wide and shallow sandbedded braided river with numerous variously vegetated bars and islands. From Ashland, Nebraska, to the Missouri River, the Lower Platte River flows through a narrow valley known as the Eastern Platte River Gorge (Joeckel and Henebry, 2008).

The term emergent sandbar habitat specifically refers to the high-elevation unvegetated regions of dry sand on bars that are above the water surface during the tern and plover breeding season. We were unable to explicitly measure emergent sandbar habitat in this study as elevations cannot be determined from aerial photography with variable discharges. We refer to dry sand, wet sand, and braiding index and recognize that these variables will change with fluctuations in discharge.

\section{Hydrology}

The Platte River flow regime has been altered substantially, beginning in the early $19^{\text {th }}$ century and extending to the present day, by irrigation diversions and canals, dams and reservoirs, and groundwater pumping (Hadley and others, 1987; Randle and Samad, 2003). Reservoir construction on the North and South Platte Rivers has reduced total annual and mean annual flow, and substantially altered the seasonal snowmelt peaks coming from the Rocky Mountains and plains (Williams, 1978; Simons and Associates Inc., 2000; Randle and Samad, 2003). This has resulted in a reduced frequency of flows that create and maintain bare sandbar nesting habitat. Average annual flows on the Platte River have been reduced significantly because of agricultural diversions (Randle and Samad, 2003). Historically, the Platte River above the Loup River probably had experienced very low flows during the late summer, and the channel may have been at times dewatered (Hadley and others, 1987; Simons and Associates Inc., 2000). The Central Platte River often is dewatered upstream from the Loup River. The Lower Platte River's present-day flow regime is characterized by cyclical daily flow changes from hydropower peaking upstream, as seen in instantaneous discharge data for the Platte River at North Bend, Nebraska (fig. 2). Such flow fluctuations make it challenging to acquire aerial photography for any large segment of river at a similar discharge.

The Loup River, Elkhorn River, and Salt Creek are tributaries that enter the Platte River 166.5, 52, and 43 river $\mathrm{km}$, respectively, upstream from the mouth of the Platte at the Missouri River. These tributaries retain a seasonal flow pattern with flood peaks corresponding to spring and early summer months and low flows in the late summer (fig. 2) and also contribute sediment to the Lower Platte River. The Loup River power canal near Genoa, Nebraska contributes fluctuating discharge from hydropower production and enters the Platte River just downstream from the Loup River, $163 \mathrm{~km}$ upstream from the Missouri River (fig. 2). The Platte River streamflow gage at Louisville, Nebraska, is located downstream from where the Loup River, Loup power canal, Elkhorn River, and Salt Creek flow into the Lower Platte River (figs. 1-2). The daily minimum and maximum discharges at the Louisville gage illustrate the effects of power peaking in the Lower Platte River (fig. 2, table 1).

\section{Geomorphology}

Since the mid- $19^{\text {th }}$ century, the Platte River's active channel has experienced a reduction in width and an increase in woody vegetation (Johnson, 1994; Simons and Associates Inc., 2000; Randle and Samad, 2003; Murphy and others, 2004; National Research Council, 2004). Most research has focused on narrowing of the active Platte River channel upstream from Grand Island, Nebraska. Average channel width measurements from maps and aerial photographs on the Platte River from North Platte to Grand Island, Nebraska, show channel narrowing varying from 87-54 percent from 1865 to 1998 (Murphy and others, 2004). A recent study of the geomorphic history of the Lower Platte River, specifically downstream from Grand Island, Nebraska, demonstrates that the history of the Lower Platte differs from the central and western Platte River (Joeckel and Henebry, 2008). Lower rates of channel area reduction and higher rates of bank erosion were measured from 1860-2005 in the reaches of the Lower Platte downstream from the Loup and Elkhorn Rivers compared to the upstream reaches (Joeckel and Henebry, 2008). 

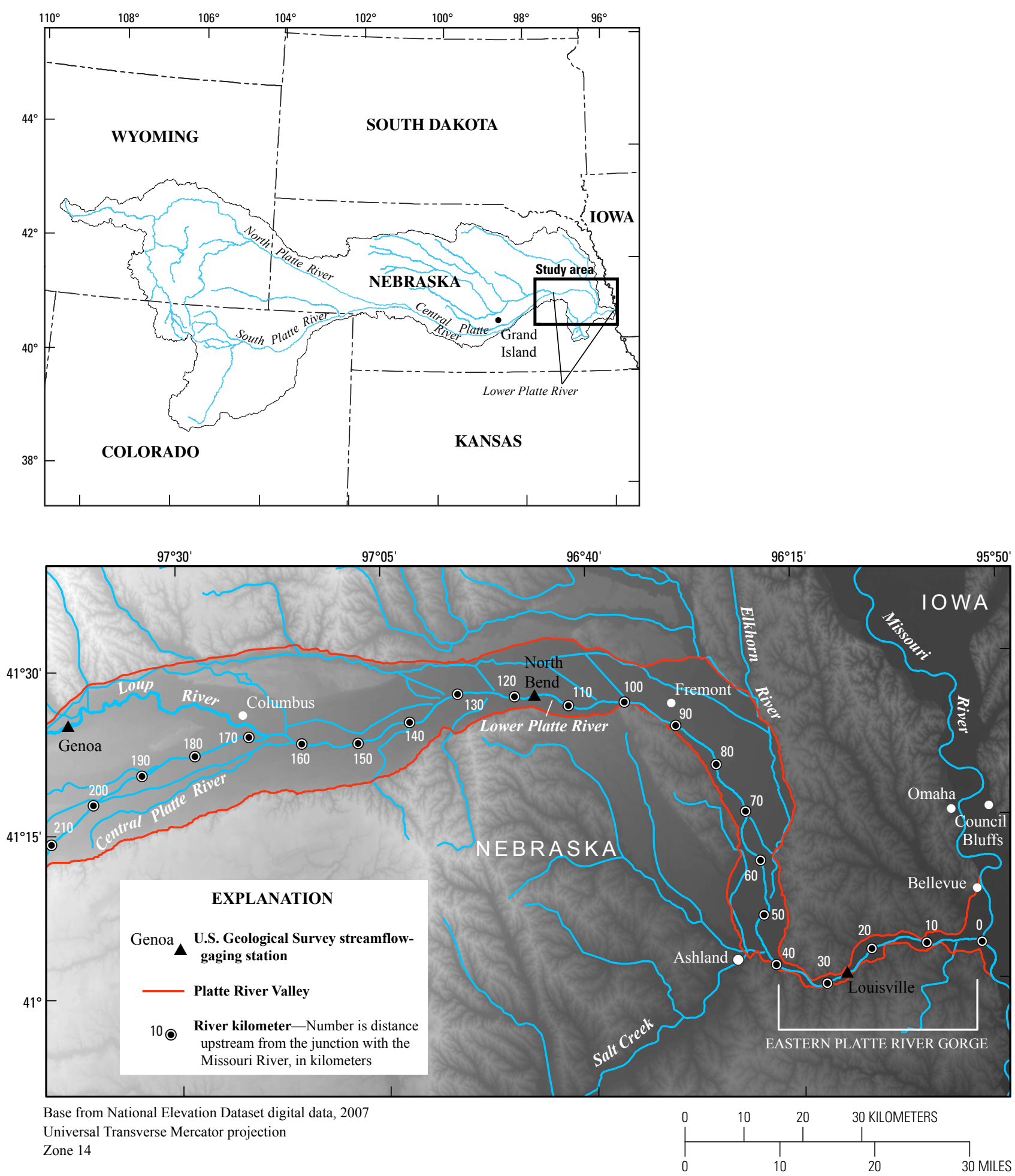

Figure 1. The Platte River Basin and the Lower Platte River study area. 

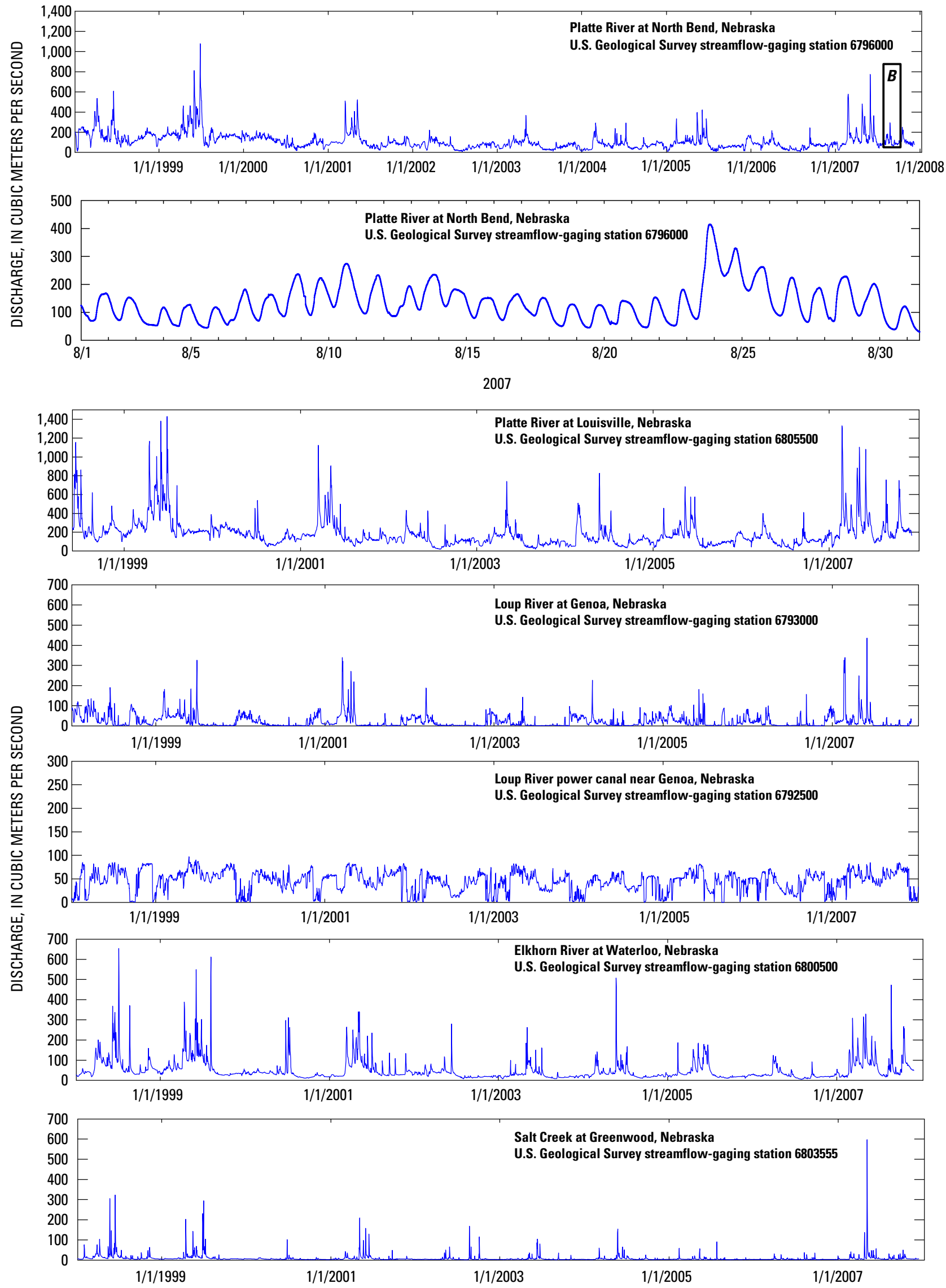

Figure 2. Discharge for the Lower Platte River and tributaries. 
Table 1. Dates and river discharges for 2006 digital photography.

[NAIP, National Aerial Imagery Program; km, distance upstream from the Platte River's junction with the Missouri River, in kilometers; $\mathrm{m}^{3} / \mathrm{s}$, cubic meters per second; Platte River streamflow-gaging stations and identification numbers: Grand Island, Nebraska, 6770500; North Bend, Nebraska, 6796000; and Louisville, Nebraska, 6805500]

\begin{tabular}{|c|c|c|c|c|c|c|c|}
\hline $\begin{array}{c}2006 \\
\text { NAIP } \\
\text { quarter } \\
\text { quadrangle }\end{array}$ & Image date & $\begin{array}{l}\text { Beginning } \\
\text { river } \\
(\mathbf{k m})\end{array}$ & $\begin{array}{l}\text { Ending } \\
\text { river } \\
(\mathbf{k m})\end{array}$ & $\begin{array}{c}\text { Maximum } \\
\text { discharge } \\
\left(\mathrm{m}^{3} / \mathrm{s}\right)\end{array}$ & $\begin{array}{c}\text { Minimum } \\
\text { discharge } \\
\left(\mathrm{m}^{3} / \mathrm{s}\right)\end{array}$ & $\begin{array}{c}\text { Mean } \\
\text { discharge } \\
\left(\mathrm{m}^{3} / \mathrm{s}\right)\end{array}$ & $\begin{array}{c}\text { Nearest } \\
\text { streamflow } \\
\text { gage }\end{array}$ \\
\hline Clarks SW & $7 / 24 / 2006$ & 216.0 & 209.0 & 0 & 0 & 0 & Grand Island \\
\hline Clarks NE & $7 / 30 / 2006$ & 216.0 & 209.0 & 0 & 0 & 0 & Grand Island \\
\hline Swedehome NW & $7 / 29 / 2006$ & 208.5 & 207.5 & 0 & 0 & 0 & Grand Island \\
\hline Silver Creek SW & $7 / 29 / 2006$ & 207.5 & 195.0 & 0 & 0 & 0 & Grand Island \\
\hline Silver Creek SE & $7 / 29 / 2006$ & 207.5 & 195.0 & 0 & 0 & 0 & Grand Island \\
\hline Silver Creek SE NW & $7 / 29 / 2006$ & 195.0 & 183.0 & 0 & 0 & 0 & Grand Island \\
\hline Silver Creek SE NE & $7 / 29 / 2006$ & 195.0 & 183.0 & 0 & 0 & 0 & Grand Island \\
\hline Columbus SW NE & $7 / 26 / 2006$ & 183.0 & 178.0 & 0 & 0 & 0 & Grand Island \\
\hline Duncan SE & $7 / 26 / 2006$ & 178.0 & 171.5 & 0 & 0 & 0 & Grand Island \\
\hline Columbus SE & $7 / 26 / 2006$ & 171.5 & 160 & 0 & 0 & 0 & Grand Island \\
\hline Columbus SW & $7 / 26 / 2006$ & 171.5 & 160 & 0 & 0 & 0 & Grand Island \\
\hline Richland SE & $7 / 23 / 2006$ & 160 & 149.0 & 32.28 & 6.65 & 15.89 & North Bend \\
\hline Richland SW & $7 / 23 / 2006$ & 160 & 149.0 & 32.28 & 6.65 & 15.89 & North Bend \\
\hline Schuyler SE & $7 / 22 / 2006$ & 149.0 & 137.5 & 26.87 & 8.78 & 17.08 & North Bend \\
\hline Schuyler SW & $7 / 22 / 2006$ & 149.0 & 137.5 & 26.87 & 8.78 & 17.08 & North Bend \\
\hline Rogers NE & $7 / 29 / 2006$ & 137.5 & 125.5 & 25.43 & 9.29 & 16.45 & North Bend \\
\hline Rogers NW & $7 / 22 / 2006$ & 137.5 & 125.5 & 26.87 & 8.78 & 17.08 & North Bend \\
\hline Rogers SW & $7 / 22 / 2006$ & 137.5 & 125.5 & 26.87 & 8.78 & 17.08 & North Bend \\
\hline North Bend NW & $7 / 29 / 2006$ & 125.5 & 114.5 & 25.43 & 9.29 & 16.45 & North Bend \\
\hline North Bend NE & $7 / 29 / 2006$ & 125.5 & 114.5 & 25.43 & 9.29 & 16.45 & North Bend \\
\hline Malmo NW NE & $7 / 28 / 2006$ & 114.5 & 103.0 & 26.50 & 7.28 & 15.57 & North Bend \\
\hline Malmo NW SE & $7 / 28 / 2006$ & 114.5 & 103.0 & 26.50 & 7.28 & 15.57 & North Bend \\
\hline Malmo NW NW & $7 / 29 / 2006$ & 114.5 & 103.0 & 25.43 & 9.29 & 16.45 & North Bend \\
\hline Malmo NW SW & $7 / 29 / 2006$ & 114.5 & 103.0 & 25.43 & 9.29 & 16.45 & North Bend \\
\hline Fremont West NW & $7 / 28 / 2006$ & 103.0 & 91.0 & 26.50 & 7.28 & 15.57 & North Bend \\
\hline Fremont West SE & $7 / 28 / 2006$ & 103.0 & 91.0 & 26.50 & 7.28 & 15.57 & North Bend \\
\hline Fremont West SW & $7 / 28 / 2006$ & 103.0 & 91.0 & 26.50 & 7.28 & 15.57 & North Bend \\
\hline Fremont East SW & $7 / 28 / 2006$ & 91.0 & 85.5 & 26.50 & 7.28 & 15.57 & North Bend \\
\hline Leshara NE & $7 / 28 / 2006$ & 85.5 & 74.0 & 26.50 & 7.28 & 15.57 & North Bend \\
\hline Leshara SE & $7 / 28 / 2006$ & 85.5 & 74.0 & 26.50 & 7.28 & 15.57 & North Bend \\
\hline Valley SW & $7 / 28 / 2006$ & 74.0 & 68.5 & 25.29 & 17.73 & 7.56 & Louisville \\
\hline Wann NE & $7 / 19 / 2006$ & 68.5 & 53.0 & 38.23 & 26.59 & 11.64 & Louisville \\
\hline Wann SE & $7 / 19 / 2006$ & 68.5 & 53.0 & 38.23 & 26.59 & 11.64 & Louisville \\
\hline Wann NW & $7 / 28 / 2006$ & 68.5 & 53.0 & 25.29 & 17.73 & 7.56 & Louisville \\
\hline Wann SW & $7 / 28 / 2006$ & 68.5 & 53.0 & 25.29 & 17.73 & 7.56 & Louisville \\
\hline Ashland East NE & $7 / 19 / 2006$ & 53.0 & 35.5 & 38.23 & 26.59 & 11.64 & Louisville \\
\hline Ashland East SE & $7 / 19 / 2006$ & 53.0 & 35.5 & 38.23 & 26.59 & 11.64 & Louisville \\
\hline Ashland East NW & $7 / 28 / 2006$ & 53.0 & 35.5 & 25.29 & 17.73 & 7.56 & Louisville \\
\hline Ashland East SW & $7 / 28 / 2006$ & 53.0 & 35.5 & 25.29 & 17.73 & 7.56 & Louisville \\
\hline Springfield SW & $7 / 19 / 2006$ & 35.5 & 33.0 & 38.23 & 26.59 & 11.64 & Louisville \\
\hline Manley NE & $7 / 19 / 2006$ & 33.0 & 29.5 & 38.23 & 26.59 & 11.64 & Louisville \\
\hline Springfield SE & $7 / 19 / 2006$ & 29.5 & 22.5 & 38.23 & 26.59 & 11.64 & Louisville \\
\hline Cedar Creek NW & $7 / 19 / 2006$ & 22.5 & 10.5 & 38.23 & 26.59 & 11.64 & Louisville \\
\hline Cedar Creek NE & $7 / 18 / 2006$ & 22.5 & 10.5 & 52.39 & 31.15 & 21.24 & Louisville \\
\hline Plattsmouth NE & $7 / 18 / 2006$ & 10.5 & 0 & 52.39 & 31.15 & 21.24 & Louisville \\
\hline Plattsmouth NW & $7 / 18 / 2006$ & 10.5 & 0 & 52.39 & 31.15 & 21.24 & Louisville \\
\hline Plattsmouth SE & $7 / 18 / 2006$ & 10.5 & 0 & 52.39 & 31.15 & 21.24 & Louisville \\
\hline Plattsmouth SW & $7 / 18 / 2006$ & 10.5 & 0 & 52.39 & 31.15 & 21.24 & Louisville \\
\hline
\end{tabular}




\section{River Classification}

River classification typically is based on one of two broad approaches. In the first, pre-determined classification schemes are applied to assign parts of a river to physically meaningful classification units. For example, an a priori classification of the Lower Platte River might be based on the major hydrologic segments (Loup River to Elkhorn River, Elkhorn River to Salt Creek, Salt Creek to the mouth) assuming that geomorphology and physical habitat will be controlled primarily by variation in flow and sediment regimes associated with the main tributaries.

A contrasting approach is to measure a suite of channelgeomorphology characteristics and to apply multivariate statistical techniques to extract naturally occurring clusters of characteristics. Statistical classification schemes have advantages in minimizing dependence on prior, potentially untested assumptions. Previous work has illustrated the broad framework of statistical approaches to river classification (Kondolf and others, 2003), although much of the existing literature focuses on classifying drainage basins (Higgins and others, 2005; Keaton and others, 2005) or valley segments (Rabeni and Sowa, 2002; Sowa and others, 2005) at broader scales than the reach scale addressed in this study. Within the clustering approach, two contrasting strategies exist. In the first, a large suite of potentially applicable variables is assembled and subjected to an ordination procedure (such as Principal Component Analysis, PCA) to explore relations among potentially redundant variables and to reduce variables to factor scores. These data then are subjected to a clustering analysis to assess how the factor scores cluster. Assigned clusters can be used as the basis for a discriminant analysis to define the mathematical functions that best describe the classified clusters.

A variation on this general strategy is to explore variables and reduce them using scientific judgment to select specific variables containing the most useful information content. In effect, this approach is a hybrid of the a priori and statistical methods because physical understanding is used to select the relevant variables. Variables chosen in this fashion may not have as much statistical power to define individual clusters, but they are more amenable to physical interpretation compared to multivariate factors that would reflect interactions of several variables.

A key step in variable selection is to define variables that are potentially controlling or independent variables, and which are adjustable, or dependent, variables. Geomorphic variables can be considered dependent or independent, depending on the time-frame and spatial extent of interest (Schumm and Lichty, 1963; Piégay and Schumm, 2003). In order to scale this analysis to management issues, our emphasis is on variables that can be considered independent over decadal time scales and $1-100-\mathrm{km}$ spatial scales. In this context, valley width, active channel width, bedrock interactions, engineered structures, and broad-scale sinuosity can be considered independent variables.
The Lower Platte River is an especially dynamic river channel with braid bars and shifting channels that change rapidly at the scale of 10's to 100's of meters (m). In addition, the Lower Platte River is subject to rapidly varying discharge because of reservoir releases and natural hydrologic events. Because of this dynamic nature, remotely sensed images rarely capture equivalent hydrologic conditions along the river. Therefore, classification approaches need to emphasize features that are relatively independent of short-term channel dynamics and hydrologic condition. Reliance on remotely sensed imagery also dictates a classification that can resolve channel features at the reach scale (1,000-10,000's m). Finerscale classifications at the channel unit and meso-habitat scale (Frissell and others, 1986) will require more intensive approaches.

The Lower Platte River also is characterized by dynamic changes to vegetation communities on sandbars, such that bars may exist in a range of vegetated conditions. Although channel characteristics and riparian vegetation communities interact to affect many channel morphological features, the potential for sandbars to become vegetated or remain unvegetated largely is a function of physical condition of a channel, including the flow regime, sediment regime, and local morphologic conditions that determine shear stress and sediment transport. Therefore, we treat the vegetation status of sandbars as a dependent variable in this classification.

\section{Approach and Methods}

We collected geomorphic information from highresolution remotely sensed imagery to serve as the basis for classification of the Lower Platte River. Geomorphic features that required interpretative identification were digitized from the imagery and image classification techniques were used to automate mapping of in-channel features (sandbars, vegetated bars, braiding index). The geomorphic information was attributed to address points at $500 \mathrm{~m}$ spacing along the channel and analyzed statistically for naturally occurring classification units.

\section{Aerial Orthophotography}

We used 2-m resolution digital natural-color orthophotograph quarter-quadrangles (DOQQ) from 2006 taken by the Farm Service Agency's National Agricultural Imagery Program (FSA/NAIP). Variations in photograph dates and significant temporal variation in discharge unavoidably led to non-uniform hydrologic conditions within the imagery set for each year (fig. 3, table 1). Aerial photography dates ranged from July 18 to July 30 . During this time, the discharge was zero at the Grand Island, Nebraska, streamflow gage upstream from the study area, and the channel was essentially dewatered upstream from the Loup River and Loup River Power Canal (fig. 3, table 1). Downstream from the Loup River and power 


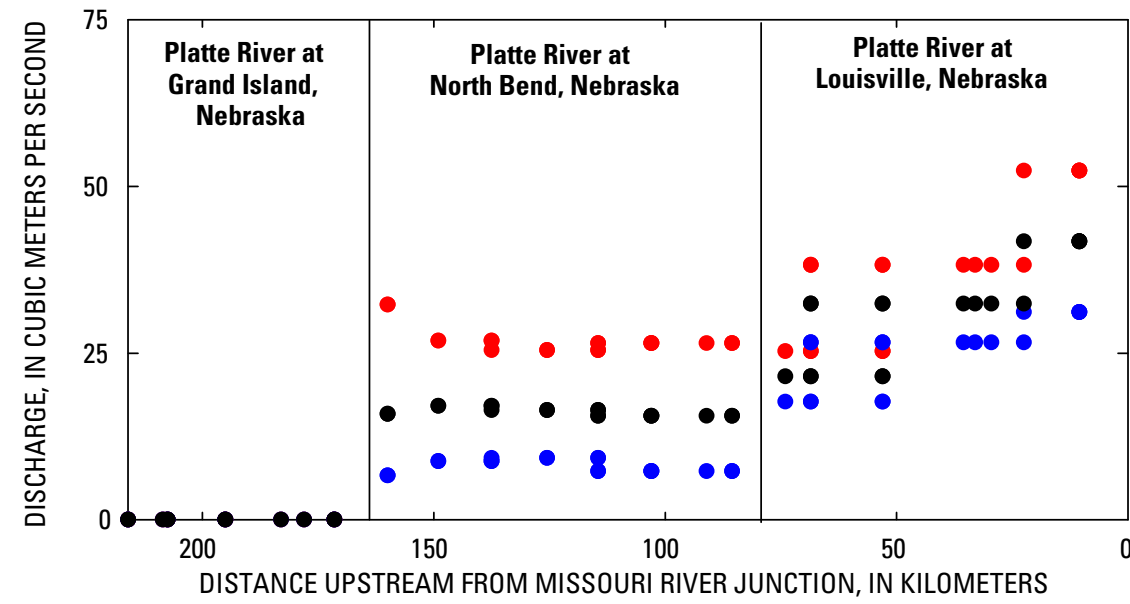

EXPLANATION

Daily discharge for aerial photographs

- Maximum

- Minimum

- Average

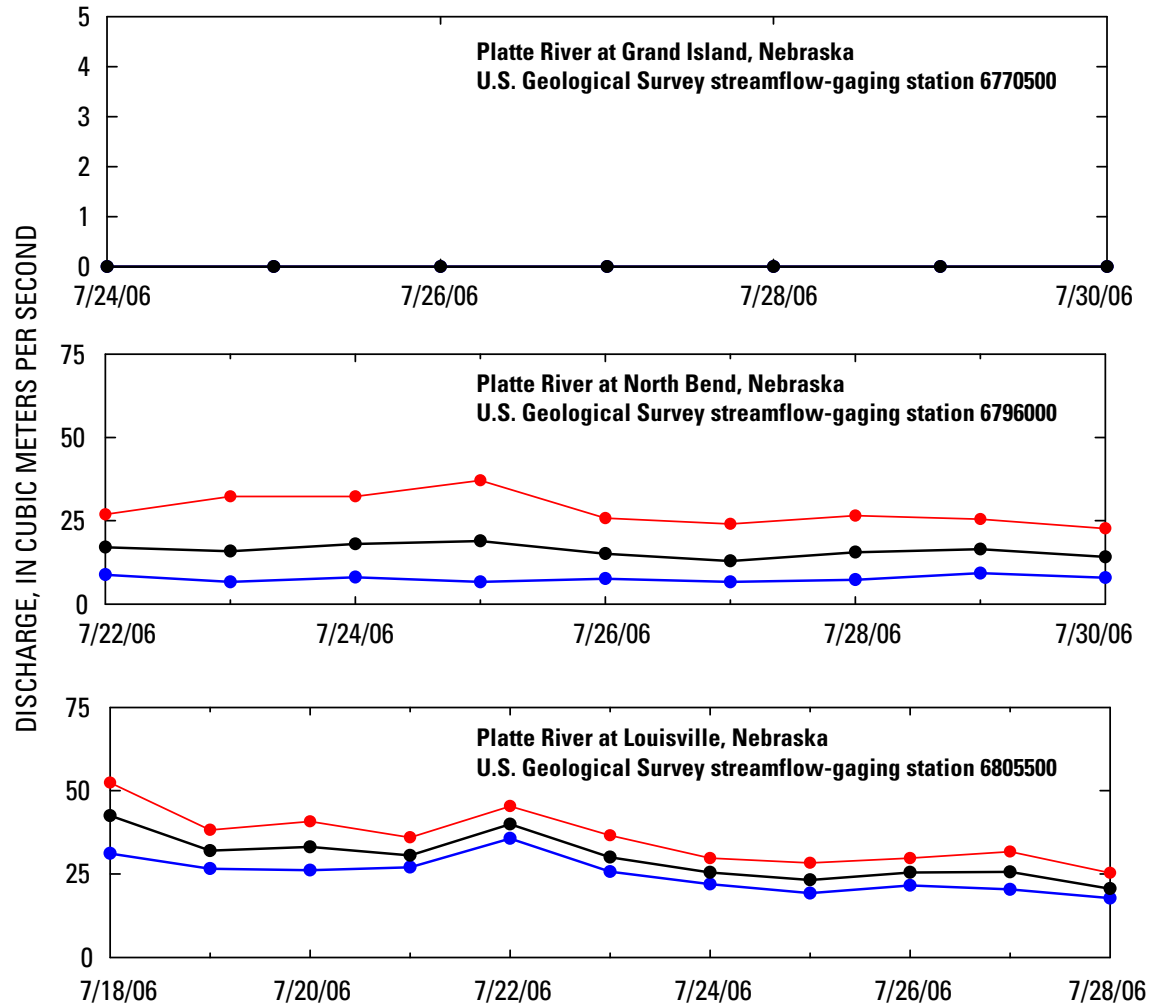

\section{EXPLANATION}

Daily discharge

$\multimap$ Maximum

$\multimap$ Minimum

$\longrightarrow$ Mean

Figure 3. Locations and discharges on the Lower Platte River for 2006 National Aerial Imagery Program photographs used in this study at the Grand Island, North Bend, and Louisville streamflow gages on the Platte River, Nebraska. 
canal differences between the daily minimum and maximum flows were between 16 and $26 \mathrm{~m}^{3} / \mathrm{s}$ (cubic meters per second) at the North Bend gage, and between 8 and $21 \mathrm{~m}^{3} / \mathrm{s}$ at the Louisville gage (fig. 3, table 1). For this reason, it was not possible to map in-channel river features over long river reaches under consistent hydrologic conditions. The photographs were mosaicked and compiled in a geographic information system (GIS) by using the ArcGIS software package (ESRI, Redlands, Calif.). All data derived from the orthophotography have the horizontal datum North American Datum, 1983 (NAD 83). The projection used for all data associated with this report is Universal Transverse Mercator, Zone 14 (UTM 14).

\section{Channel and Valley Boundary Determinations}

The river channel boundary was digitized manually on a computer screen at a 1:5,000 scale on the mosaicked 2006 orthophotography. All areas of the river that appeared to be "active channel" were digitized as part of the channel. The active channel was identified by steep slope breaks on banks, presence of open water, and geomorphic and sedimentological features indicative of frequent sediment transport. This method, as opposed to defining the channel boundary at the water's edge, allowed for comparison of channel width and other characteristics between orthophotographs with highly varied discharges.
The Platte River Valley was digitized at the same scale as the river on the 2006 orthophotography. Topographic and geologic maps as well as a Digital Elevation Model from the National Elevation Dataset (U.S. Geological Survey) aided in determining the Platte River Valley boundary.

\section{Address System}

To establish the address system, the channel centerline was drawn between the digitized channel boundaries using a computer-automated method (fig. 4). The address system and data-collection methods used are similar to those developed for the Missouri National Recreational River; see Elliott and Jacobson, (2006) for more details.

Address points were defined along this centerline with 500-m intervals, comparable to the average width of the Lower Platte channel (fig. 4). To collect attributes from raster and polygon classifications, a polygon address system was created by using generally perpendicular transects drawn through the address points to divide the channel into quadrilateral polygons (fig. 4). Address polygons were intersected with the classification raster or polygon datasets to assign attributes to address points.

The digitized channel boundary lines were converted to closely-spaced points (1-m apart) to calculate river width. A

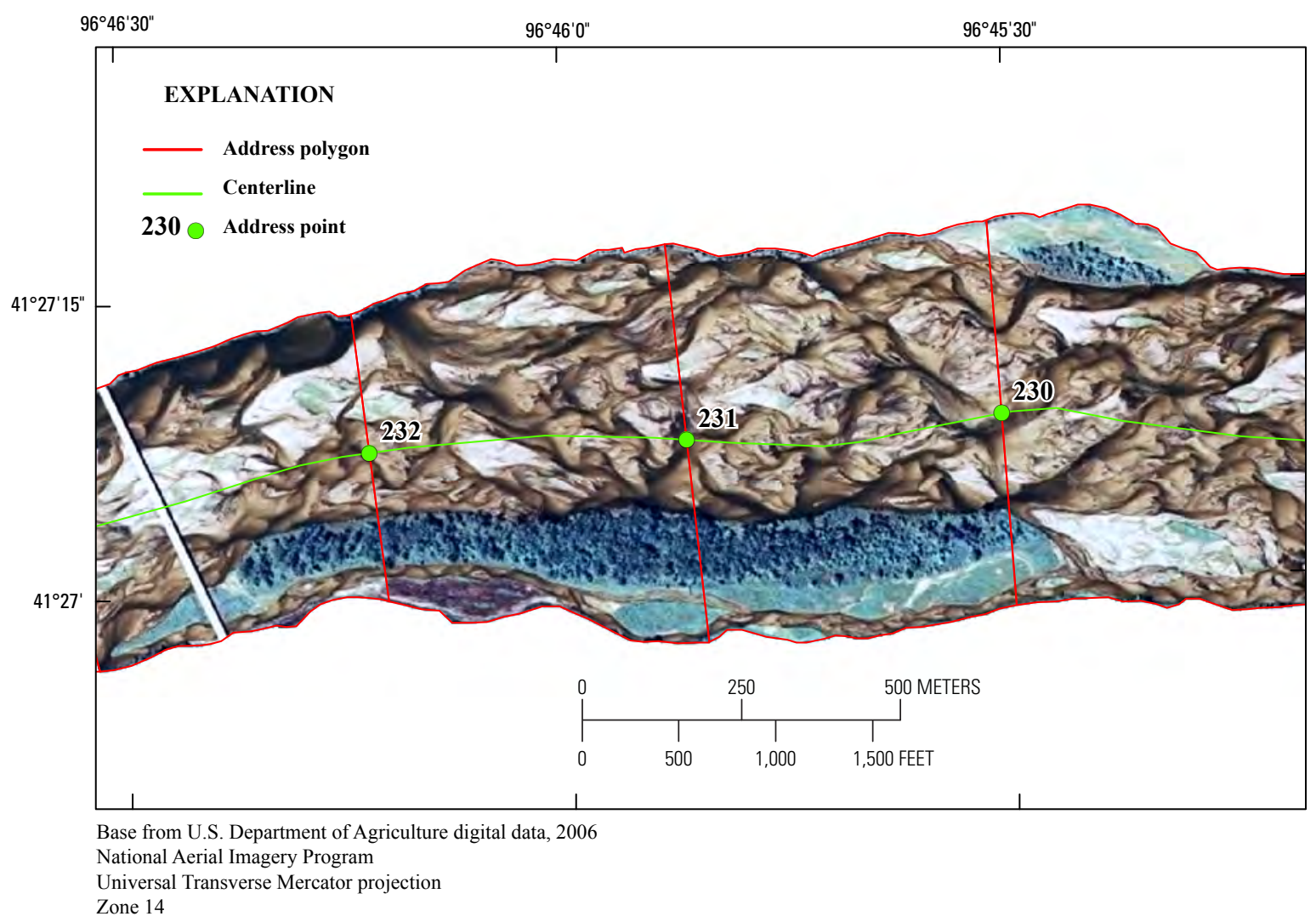

Figure 4. Address system created for data collection based on the channel centerline. Address points were created at 500 -meter intervals. Address system includes polygons that can be intersected with data for raster- or polygon-based area data collection. 
distance function was then used to measure the distance from an address point to the closest channel boundary point on the right and left banks. These values were added together to calculate total channel width. Channel width, therefore, measures the width of the active channel, including all mid-channel bars and islands, as well as sandbars along the sides of the channel. The same process was used to calculate valley widths for the Platte River Valley.

Sinuosity is calculated by dividing the distance between points as measured along the thalweg by the straight-line distance between points. Because of the highly braided nature of the Lower Platte River, we were unable to define a thalweg at the scale of braiding; therefore, we used the channel centerline as the basis for calculating a modified channel sinuosity index. This effectively defines minimum scale of sinuosity resolution. Additionally, because sinuosity can vary greatly with the scale of measurement, sinuosity values were calculated for 1,000 ; 2,000; 4,000; 8,000; and 16,000-m reaches of the Lower Platte River.

\section{Image Classification for In-Channel Characteristics}

Images were classified for the entire area within the channel boundaries for the Platte and Loup Rivers to identify in-channel characteristics. The 2006 mosaicked imagery was masked to the channel region and exported to ERDAS Imagine (Erdas Inc., Norcross, Georgia). Classification categories were selected to differentiate between deep water (channel bottom not visible), dry sand, wet sand, non-woody vegetation (light vegetation unit), and woody vegetation (dark vegetation unit). Several of the best representatives from each class were selected for use as training samples (fig. 5), and these samples then were used to generate a computerized classification of the entire in-channel area.

Although computer classification allowed for greater consistency and took much less time than manual digitization of the categories, some errors were introduced in the process. Many of the errors occurred in relation to classification of bars with woody vegetation. No consistent way was found to classify areas of nonvegetated ground within the islands, and many of the darker shadows from the woody vegetation initially were classified as deep water. Additionally, some areas of deep water were misclassified as woody vegetation.

To correct for these errors, we used the ArcMap software to convert the woody vegetation raster layer into a polygon layer. Polygons with areas less than 2,500 square meters $\left(\mathrm{m}^{2}\right)$ were deleted, which allowed for selection of only true vegetated bars, rather than areas of deep water that were misclassified as vegetation. Any holes in the remaining polygons were filled, which corrected for false classification of bare sediment and deeply, shadowed regions. These island polygons were then recombined with the initial raster classification to create a finalized classification raster.

Problems remaining in the final raster include but are not limited to: misclassification of bridges (generally as sand with the darker shadows classified as deep water); misclassification along the channel boundaries and edges of the island polygons, which could not be corrected by the process described above; gaps in the classification raster where deep

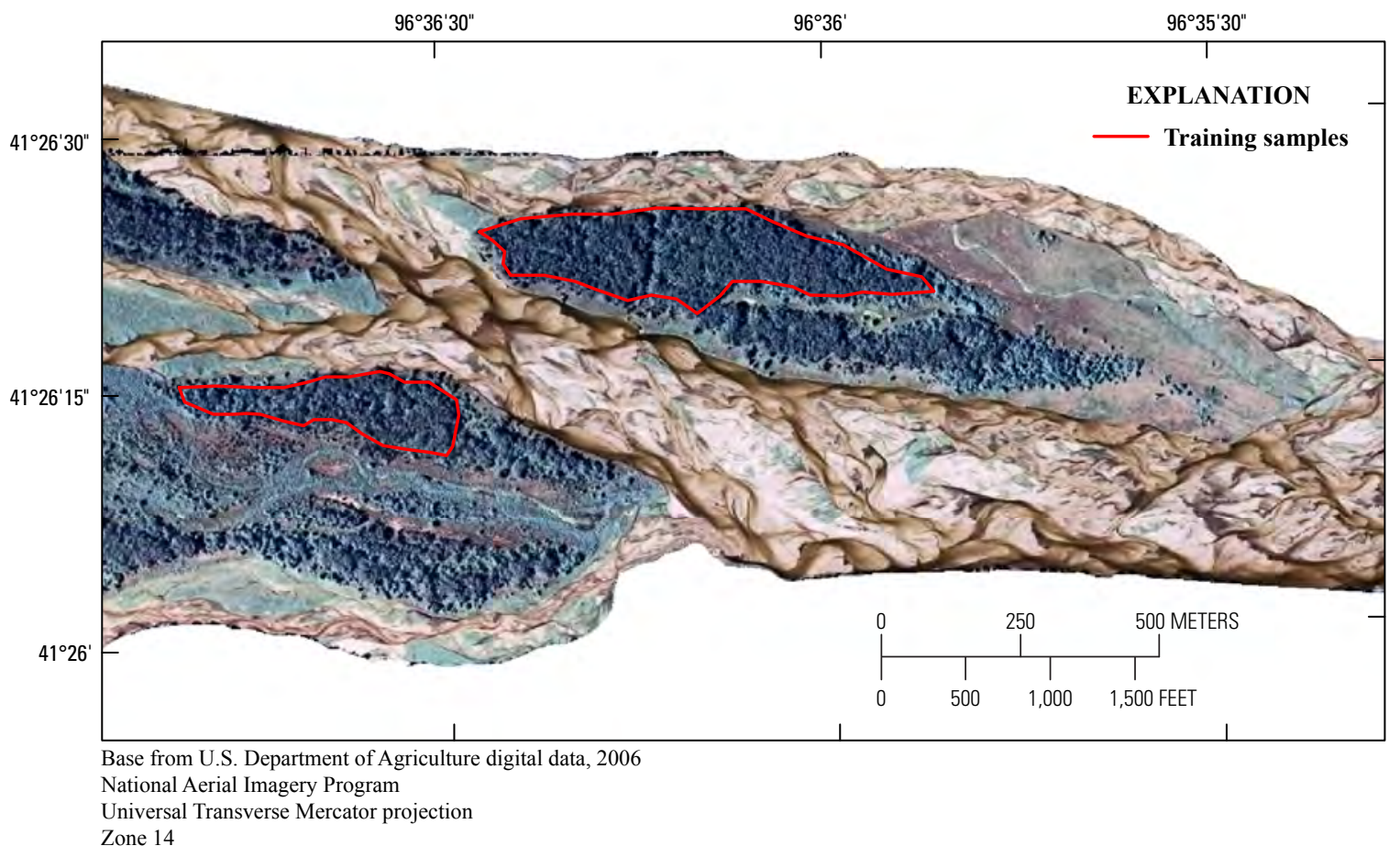

Figure 5. Selection of training samples for the woody vegetation category of the computerized classification. 
water, nonwoody vegetation, or other classes initially had been classified as woody vegetation; and misclassification of dark patches of sand as nonwoody vegetation.

In order to evaluate the effectiveness of automated classification as opposed to manual digitization of the classification categories, a 2-km representative section of river was selected for manual classification (table 2, fig. 6). The reach was interpreted manually and digitized at a scale of 1:5,000, and the entire area was classified - based on a visual estimation of color and texture - into the same categories used in the computer classification. For the purposes of the manual classification, any sandbars that were not at least 50 percent covered by vegetation were classified as bare sand.

A braiding index representing the total number of channels was calculated at each address point. Polygons created by combining the wet sand and deep water classification categories were intersected with the perpendicular transects through each address point. The number of channels was calculated by counting the number of times each transect intersected a polygon. Only intersections greater than $10 \mathrm{~m}$ long were considered to be true channel; line segments shorter than this length were disregarded. The number of bars also was calculated as a complementary metric. The number of bars within an address polygon was tabulated by counting the number of bar polygon centroids, and this number was assigned to the address point.

\section{Statistical Classification}

Geomorphic and in-channel characteristic variables and their interpretations are listed in table 3 . The addressing system allows the data to be illustrated in a longitudinal framework (fig. 7).

The address-point data were examined for correlation and to assess normality of distributions. Many of the variables are interrelated, as shown by principal component analysis (PCA, fig. 8) and scatterplots (fig. 9). The PCA shows variables related to channel complexity (braiding index, numbers of bars, channel width, and wet sand area) are related and are positively loaded on factor 1 . Importantly, dry sand area is negatively loaded on factor 1 , indicating that under the hydrologic conditions prevailing during the imagery collection in 2006 , wet, deep water areas are inversely related to dry channel areas. Dark vegetation (older, more established vegetation communities) and light vegetation (younger, less established vegetation communities) are associated with channel width (negatively loaded on factor 2) indicating that bar stability is associated with increased channel width. Deep water areas are positively associated with factor 3 , as are sinuosity at the 2,000-m and 8,000-m scales, indicating an association between channel sinuosity and flow concentration.

Table 2. Comparison of automated and manual classifications of a 2-kilometer reach of the Platte River.

\begin{tabular}{|c|c|c|c|c|c|c|c|c|}
\hline Classification & $\begin{array}{c}\text { Manual } \\
\text { deep water, } \\
\text { in number } \\
\text { of grid cells }\end{array}$ & $\begin{array}{l}\text { Manual } \\
\text { dry sand, } \\
\text { in number } \\
\text { of grid cells }\end{array}$ & $\begin{array}{l}\text { Manual } \\
\text { wet sand, } \\
\text { in number } \\
\text { of grid cells }\end{array}$ & $\begin{array}{c}\text { Manual } \\
\text { non-woody } \\
\text { vegetation, } \\
\text { in number } \\
\text { of grid cells }\end{array}$ & $\begin{array}{l}\text { Manual } \\
\text { woody } \\
\text { vegetation, } \\
\text { in number } \\
\text { of grid cells }\end{array}$ & $\begin{array}{l}\text { Manual } \\
\text { unclassified } \\
\text { (bridge), } \\
\text { in number } \\
\text { of grid cells }\end{array}$ & $\begin{array}{c}\text { Total } \\
\text { number of } \\
\text { grid cells }\end{array}$ & $\begin{array}{l}\text { Percent of total } \\
\text { grid cells in } \\
\text { agreement with } \\
\text { automated } \\
\text { classification }\end{array}$ \\
\hline $\begin{array}{l}\text { Automated deep } \\
\text { water }\end{array}$ & 6,401 & 151 & 4,134 & 322 & 241 & 22 & 11,271 & 57 \\
\hline Automated wet sand & 3,262 & 8,425 & 142,283 & 3,091 & 88 & 192 & 157,341 & 90 \\
\hline $\begin{array}{l}\text { Automated non- } \\
\text { woody vegetation }\end{array}$ & 5 & 4,803 & 3,908 & 14,139 & 205 & 42 & 23,102 & 61 \\
\hline $\begin{array}{l}\text { Automated woody } \\
\text { vegetation }\end{array}$ & 357 & 0 & 917 & 2,620 & 27,302 & 0 & 31,196 & 88 \\
\hline $\begin{array}{l}\text { Unclassified (woody } \\
\text { vegetation manu- } \\
\text { ally removed) }\end{array}$ & 1,256 & 233 & 3,347 & 2,206 & 646 & 122 & 7,810 & 16 \\
\hline $\begin{array}{l}\text { Total number of } \\
\text { grid cells }\end{array}$ & 11,318 & 43,750 & 162,509 & 23,651 & 28,487 & 1,788 & 271,503 & -- \\
\hline $\begin{array}{l}\text { Percent of total grid } \\
\text { cells in agree- } \\
\text { ment with manual } \\
\text { classification }\end{array}$ & 57 & 69 & 88 & 60 & 96 & 0 & -- & -- \\
\hline
\end{tabular}




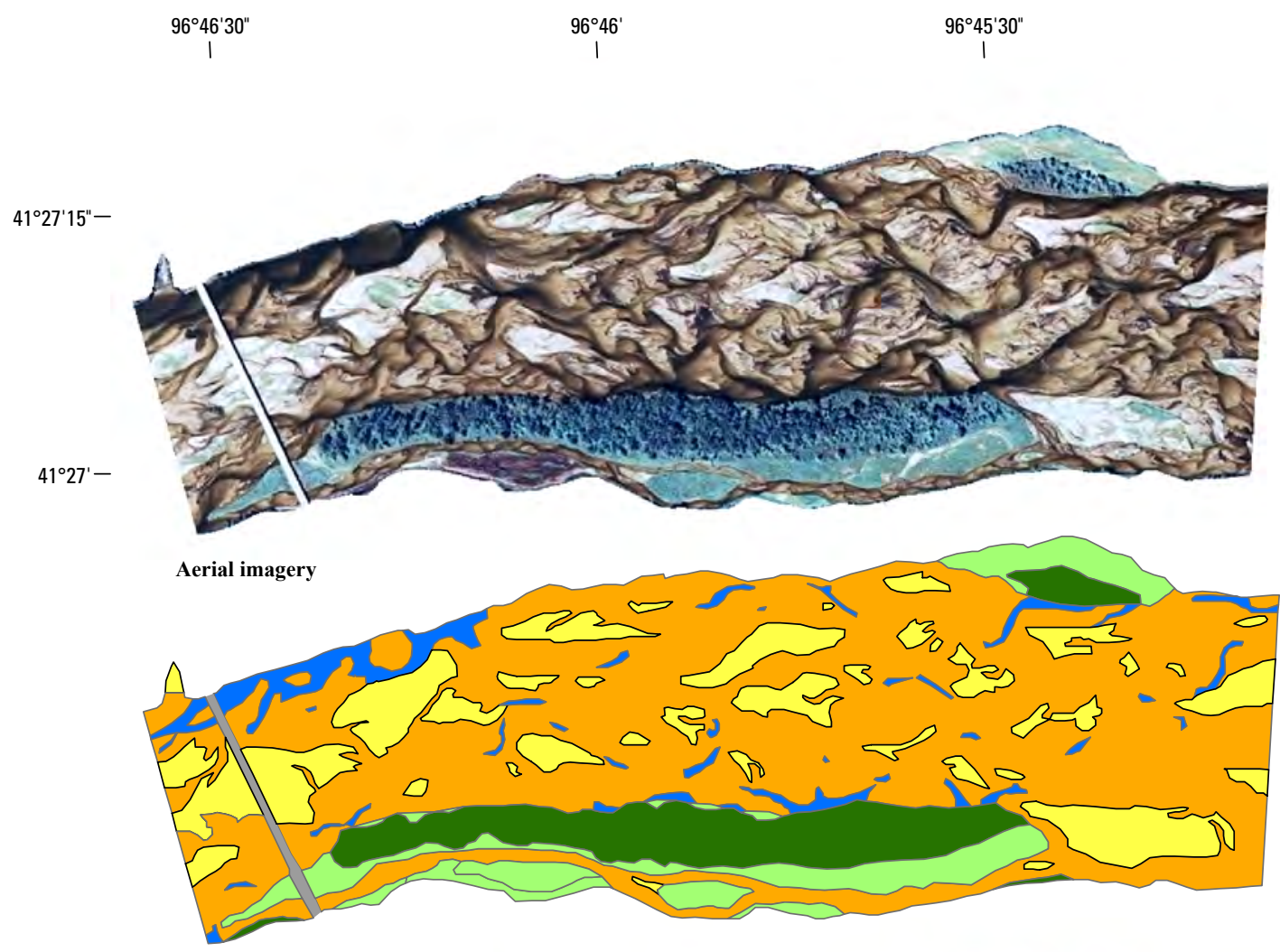

Manual classification

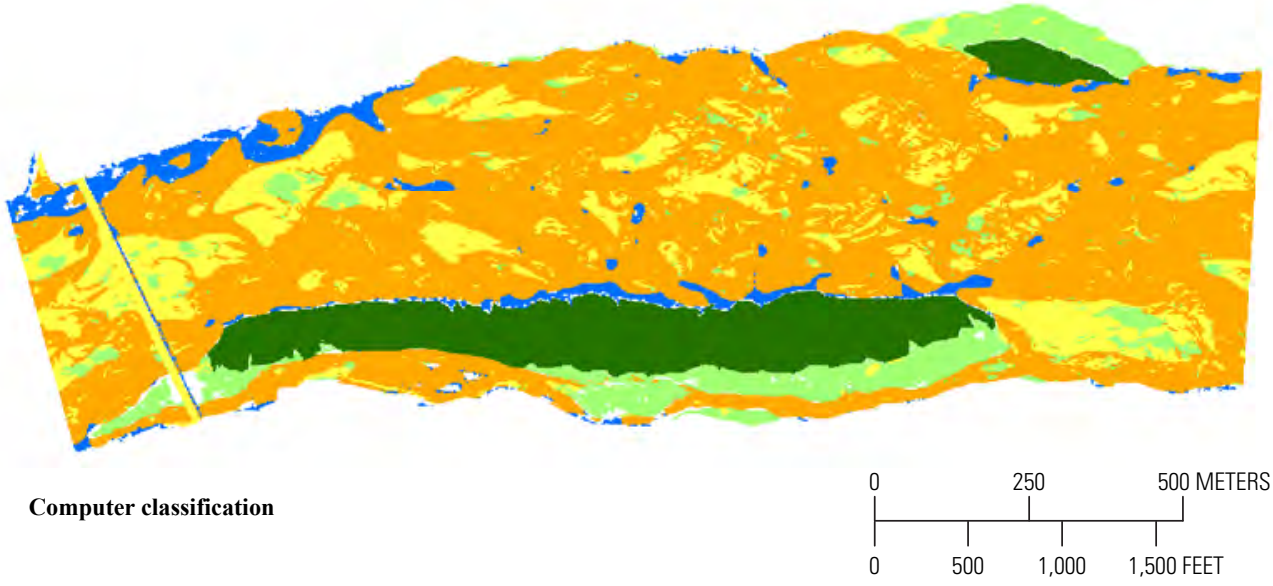

Base from U.S. Department of Agriculture digital data, 2006 National Aerial Imagery Program

Universal Transverse Mercator projection Zone 14

\section{EXPLANATION}

Deep water

Dry sand

Wet sand

Light-colored vegetation

Dark-colored vegetation

Unclassified (bridge)

Figure 6. Comparison of National Aerial Imagery Program (NAIP) photography, manual classification, and computerized classification for a 2-kilometer representative section of the Platte River. 
Table 3. Variable names, abbreviations, and definitions.

\begin{tabular}{|c|c|c|}
\hline Variable name & Abbreviation & Definition \\
\hline Channel width & CWIDTH & Width of channel, high bank to high bank, in meters perpendicular to the center line \\
\hline Valley width & VWIDTH & Valley width perpendicular to the channel center line, in meters \\
\hline Sinuosity at 8000 meters & SIN8000 & $\begin{array}{l}\text { Ratio of distance along the channel centerline over 8,000 meters to the straight-line } \\
\text { distance between the two end points }\end{array}$ \\
\hline Percent area of dry sand & DRYSAND & Percent area of dry sand identified through aerial imagery and classification \\
\hline Percent area of wet sand & WETSAND & Percent area of wet sand identified through aerial imagery and classification \\
\hline Percent area of light vegetation & LTVEG & $\begin{array}{l}\text { Percent area of light vegetation identified through aerial imagery and classification; } \\
\text { Non-woody vegetation communities }\end{array}$ \\
\hline
\end{tabular}

Through an iterative process, we focused on four key variables that were judged to be relatively independent from one another and indicative, adjustable geomorphic variables. The four variables were valley width, channel width, 2,000-m sinuosity, and 8,000-m sinuosity (fig. 10). To minimize dependence among spatially adjacent sample points in the clustering analysis, we randomly selected approximately one quarter of the points for initial clustering and analysis. The four variables were standardized by the range of values and examined for normality. Normality is not critical for cluster analysis, but is a fundamental assumption of discriminant analysis. Violation of normality, however, is not considered critical to useful analysis (Hill and Lewicki, 2006). The variables were not considered critically non-normal.

Hierarchical cluster analysis of the standardized, randomly selected dataset was used to examine the clustering structure of the dataset (fig. 11). This analysis supported identification of four distinct clusters. Additional clusters were identified but were not as clearly distinguished as the first four.

The standardized, randomly selected dataset also was analyzed by K-means cluster analysis stipulating 2 to 10 clusters. K-means cluster analysis starts with predefined number of clusters (K) and divides the data into $\mathrm{K}$ mutually exclusive groups by maximizing the between-group variation (Wilkinson and others, 2004). We used Euclidean distance as the distance metric, and a plot was developed of between-group sum of square differences and within-group sum of square differences by cluster number (fig. 12). Similar to a "scree" plot, breaks in the slopes of these curves were interpreted as numbers of clusters at which information content of the clustering process changed. The plot clearly indicates a break in slope at four clusters, similar to the hierarchical cluster result. Moreover, "cluster-parallel" plots (figs. 13, 14) indicated a divergence at eight clusters, so we also chose seven clusters as the basis for a more detailed classification. The cluster-parallel plots were arranged with the variable having the highest discrimination capability at the top of the plot and the least at the bottom.

After assigning classes for four and seven clusters, discriminant analysis was used to develop classification functions for the clusters. Discriminant analysis plots (figs. 15, 16) show distinct groupings of cluster classes along the first two factored axes. In addition, the discriminant classifications were cross validated using a jackknife procedure, which indicated that 78-100 percent of all points were correctly classified (table 4). Success in classification was least for clusters with small representation, such as clusters three, five, and six in the seven-cluster dataset.

We classified the previously non-selected three-quarters of the data points using the discriminant functions for the fourand seven-cluster cases, and transferred the classifications back to the address GIS dataset. By examining the cluster parallel and profile plots, and the physical context of the river, we assigned descriptive categories to the classes (table 5; fig. 17).

\section{Classification Assessment}

The utility of the geomorphic classification was assessed based on its ability to discriminate in-channel characteristics and to classify a limited number of tern and plover nesting locations. Variation of in-channel characteristics was assessed graphically using comparative box plots of proportions of deep water, dry sand, braiding index, and dark vegetation by four- and seven-cluster classes. To assess the utility of the classifications in identifying nesting habitat, we compared proportions of class types to proportions of nests found in those class types as mapped 2006-08 by the Nebraska Game and Parks Commission (Joel Jorgenson unpub. data, Nebraska 

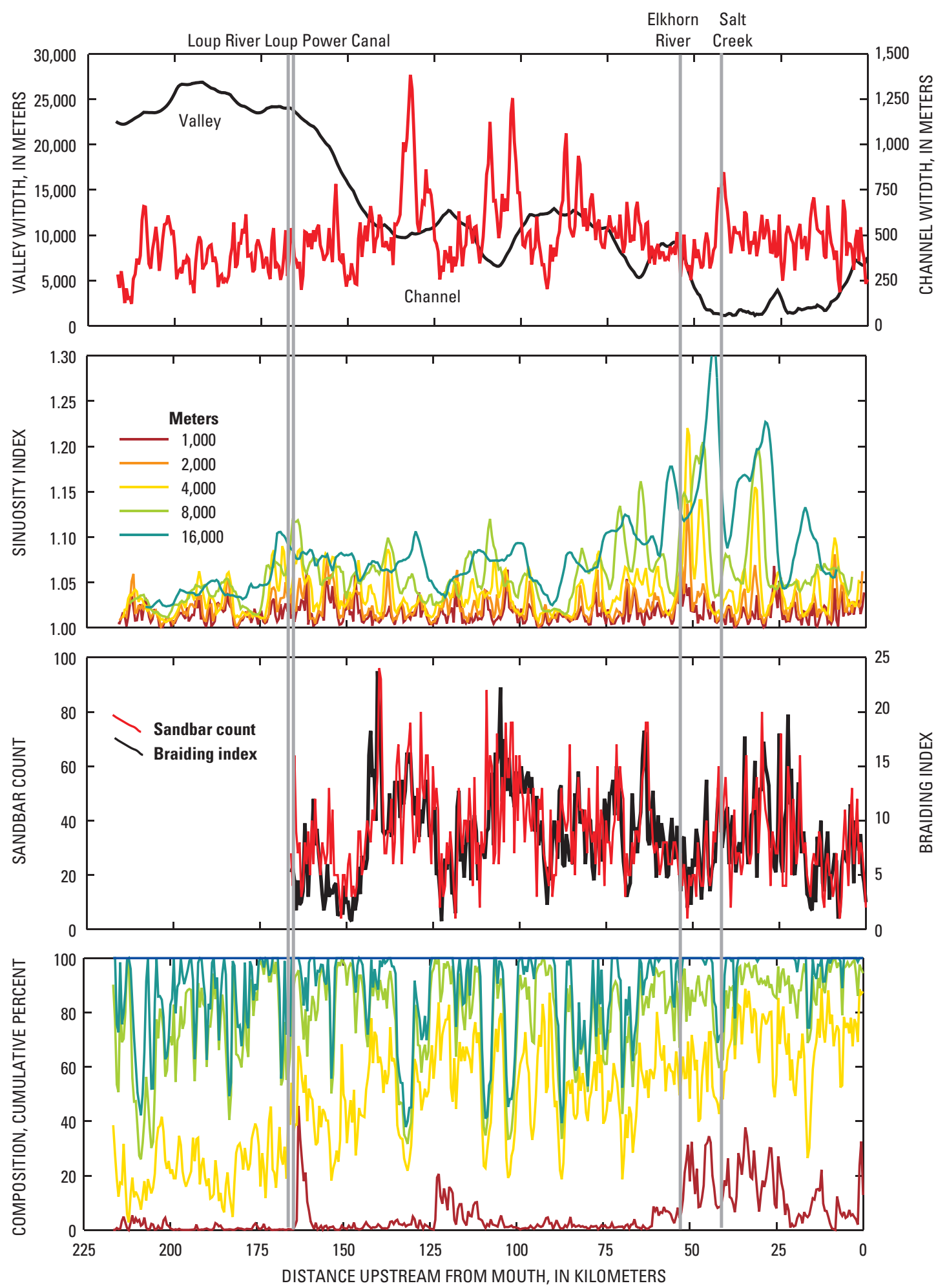

EXPLANATION

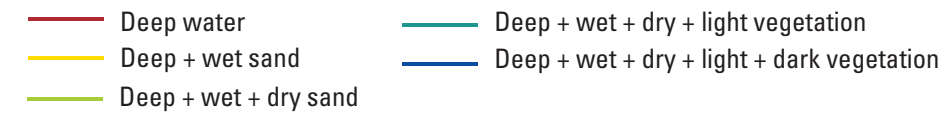

Figure 7. Platte River geomorphic characteristics including valley width, channel width, sinuosity, sandbar count, braiding index, and percent of channel composition. 


\section{Three-dimensional plot of first three axes}

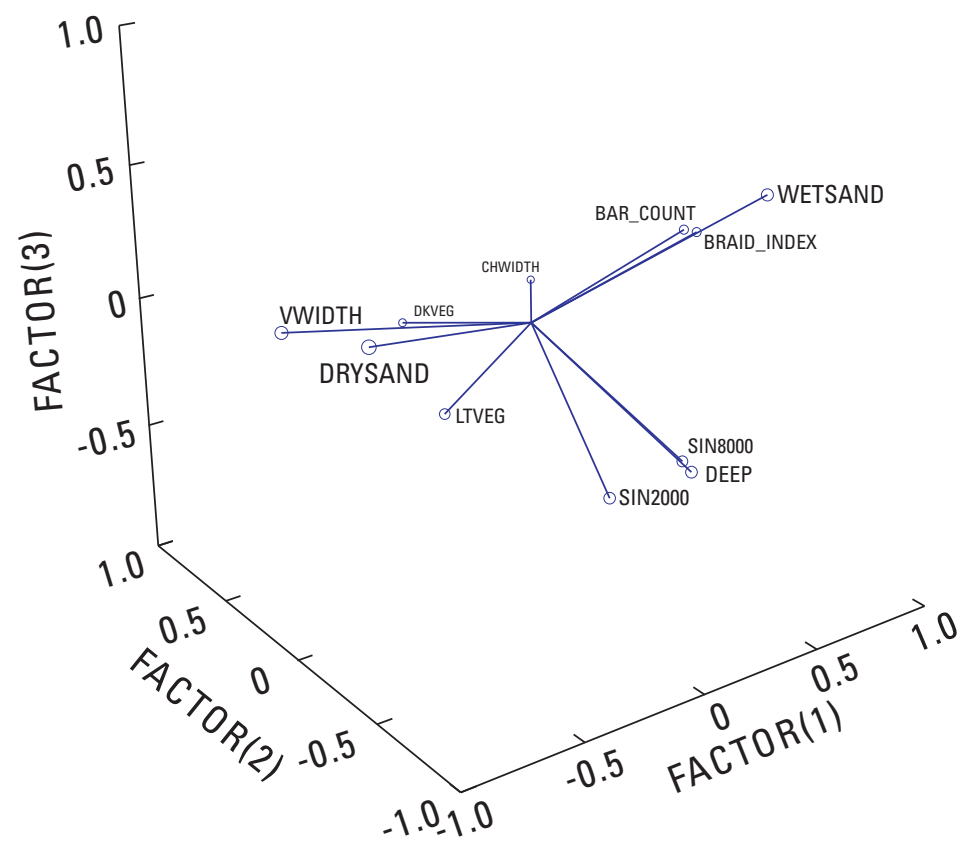

Component comparison plots

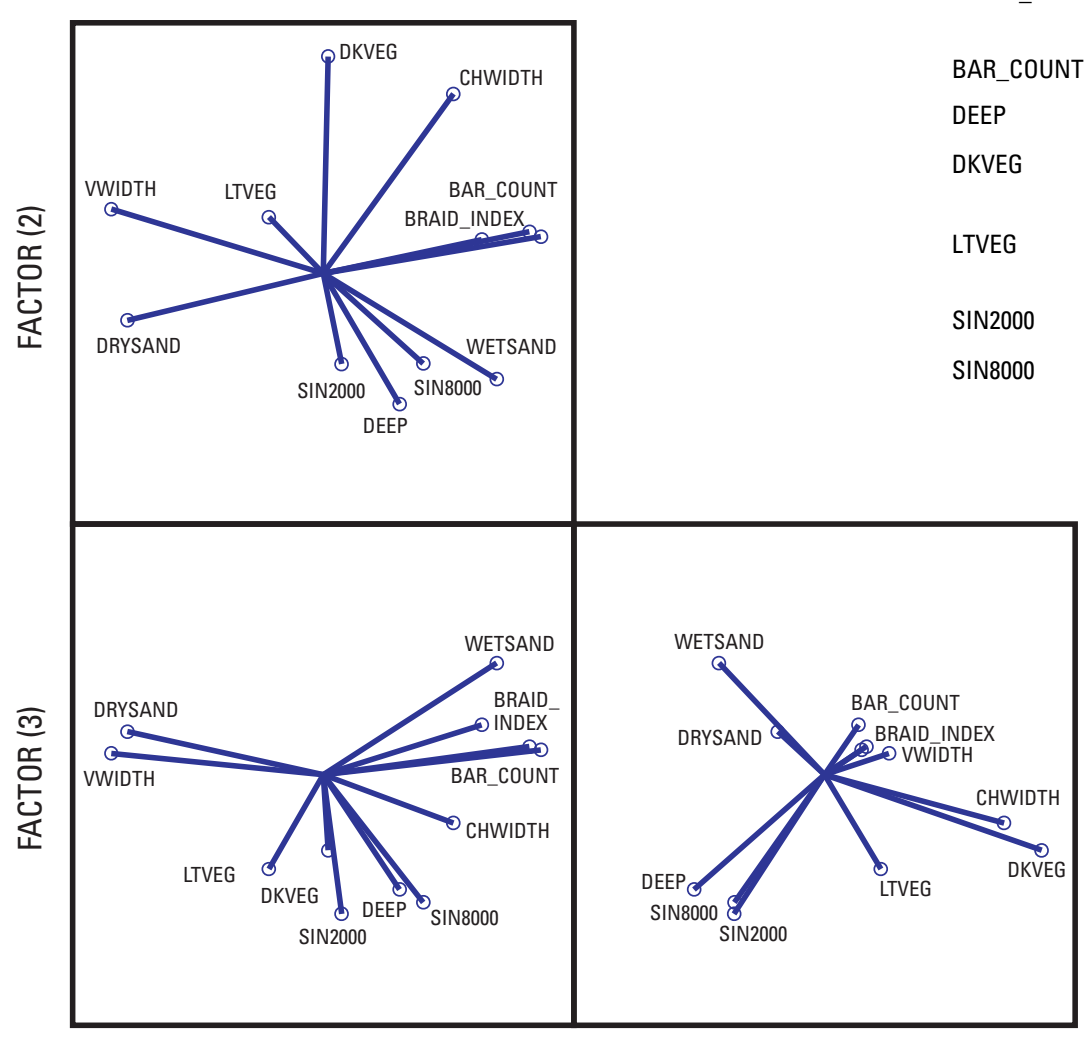

FACTOR (1)

FACTOR (2)

Figure 8. Principal components analysis of selected variables on three principal components. All variables have been standardized to the range. 


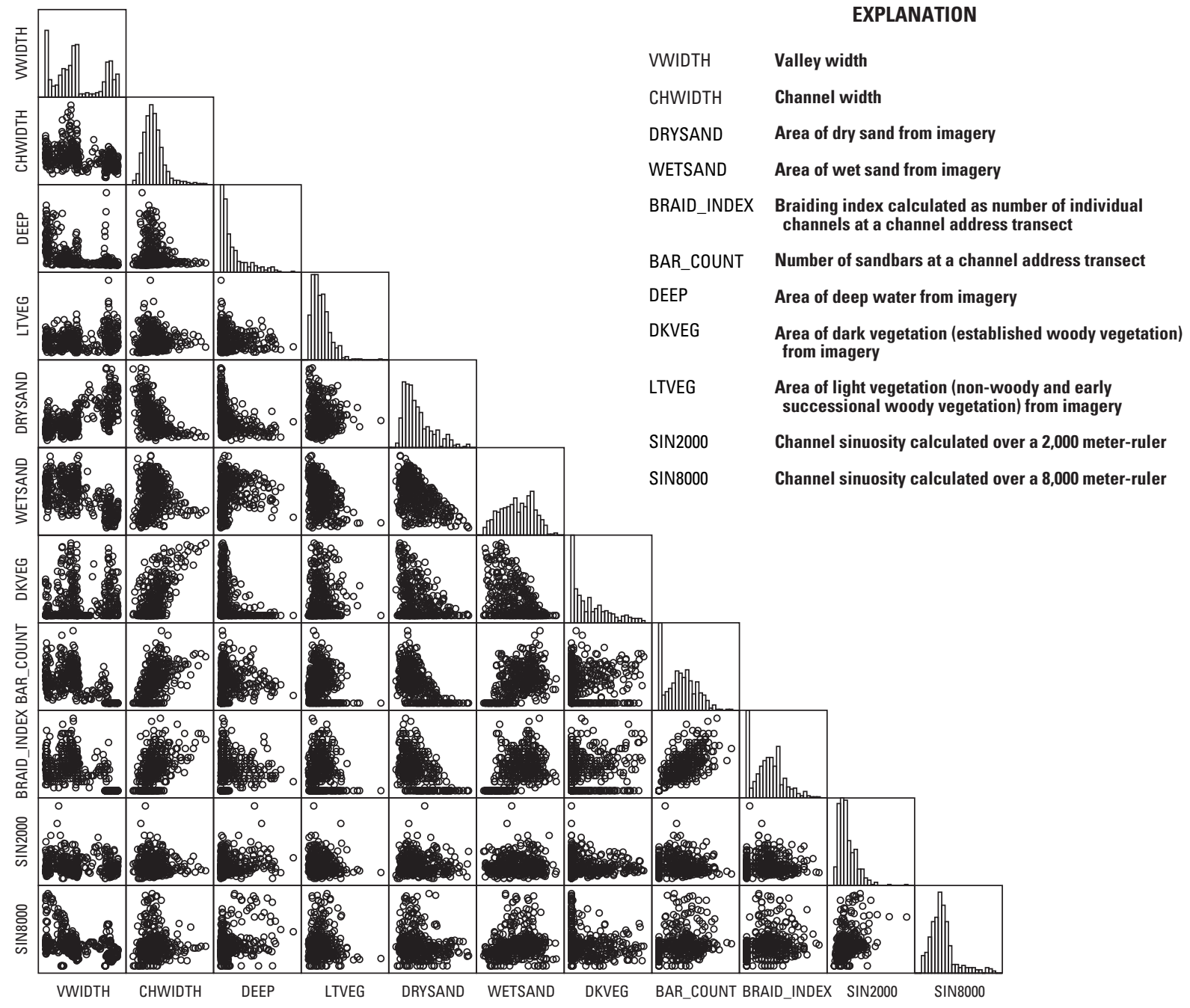

Figure 9. Selected, non-transformed classification variables.

Game and Parks Commission, 2009; Brown and Jorgenson, 2008). This dataset consisted of 265 nest locations total, 16 mapped in 2006, 85 in 2007, and 164 in 2008. Nests were located by field-based survey during the nesting season and locations were georeferenced using handheld global positioning systems to nominally $+/-5-\mathrm{m}$ accuracy. Because these data do not necessarily indicate nesting success, nest data should be viewed as a measure of physical nesting potential. Out of the 265 nests, 92 percent (245) were least tern nests. For classification validation all nests from 2006-08 and the two species were lumped together. We calculated Ivlev's selectivity coefficients to quantify the strength of nesting selection for specific river reaches (Manly and others, 2002). Selectivity coefficients were calculated as:

$$
E_{i}=\left(o_{i}-\pi_{i}\right) /\left(o_{i}+\pi_{i}\right)
$$

where $E_{i}$ is the selectivity coefficient for resource unit $i$ (from-1 to +1 ), $o_{i}$ is the sampled proportion of reaches with nests, and $\pi_{i}$ is the sampled proportion of available reaches.
Values of selectivity coefficient near 0 indicate habitat is used in proportion to its availability. Positive coefficient values indicate habitat selection, whereas negative coefficient values indicate avoidance. Although these coefficients do not indicate a probability of nesting in a reach, they do document the relative strength of selection among a range of reaches.

\section{Results}

Geomorphic and in-channel characteristics of the Lower Platte River vary substantially along its length (fig. 7). Valley width and 8,000 to $16,000-\mathrm{m}$ sinuosity vary at a broad scale, whereas short-scale sinuosity, measures of braiding, channel width, and most of the in-channel characteristics vary at a fine scale. 


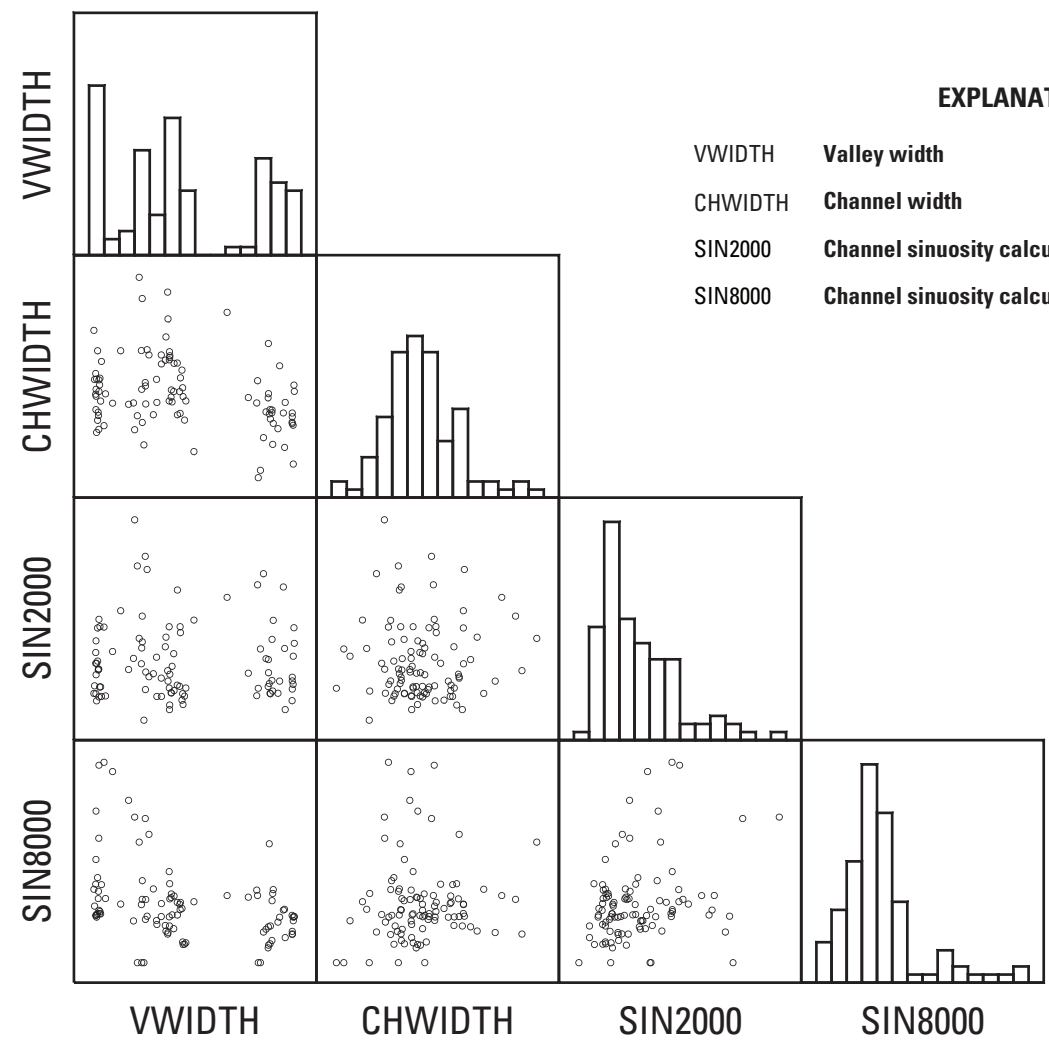

Figure 10. The reduced set of selected classification variables.

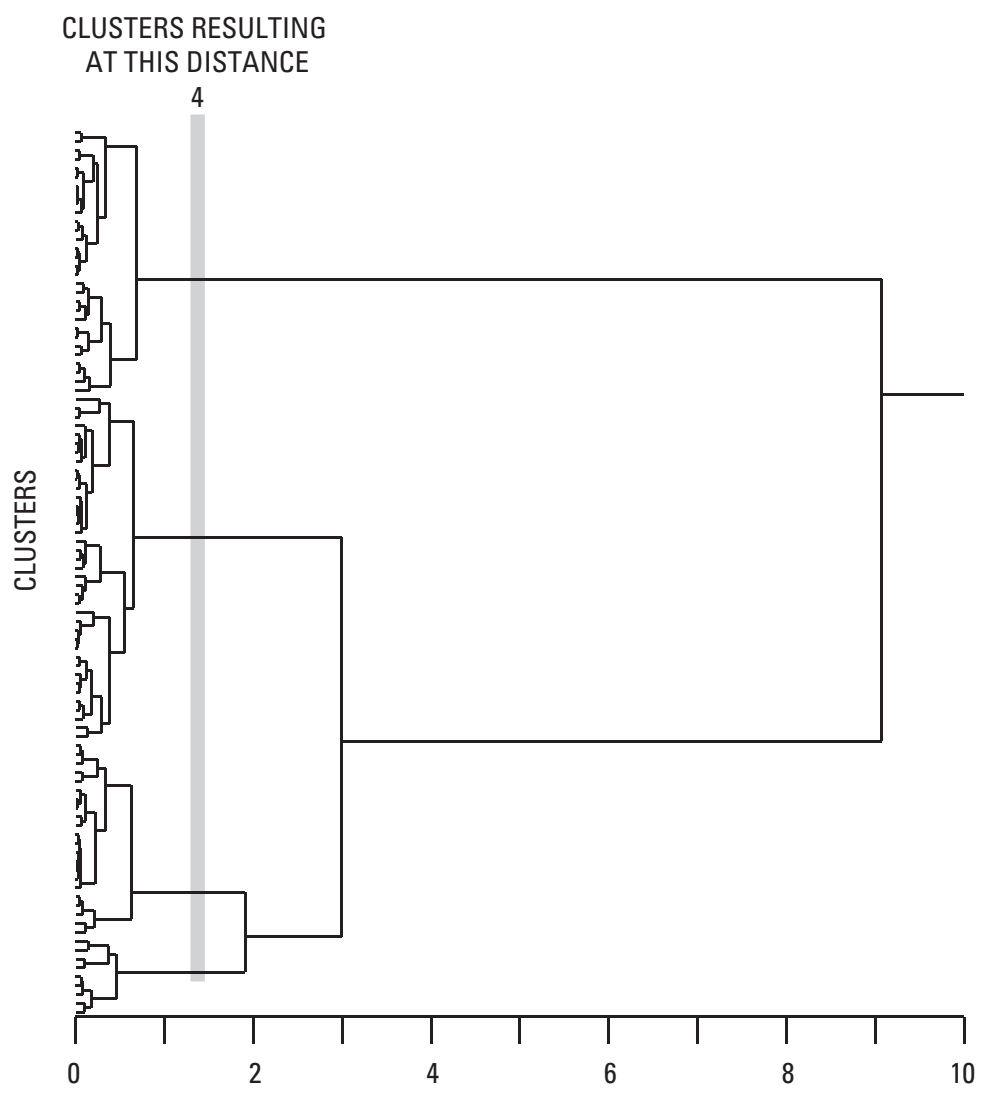

Figure 11. Hierarchical cluster dendrogram of the reduced dataset. Selected variables were standardized for this analysis. at four clusters 


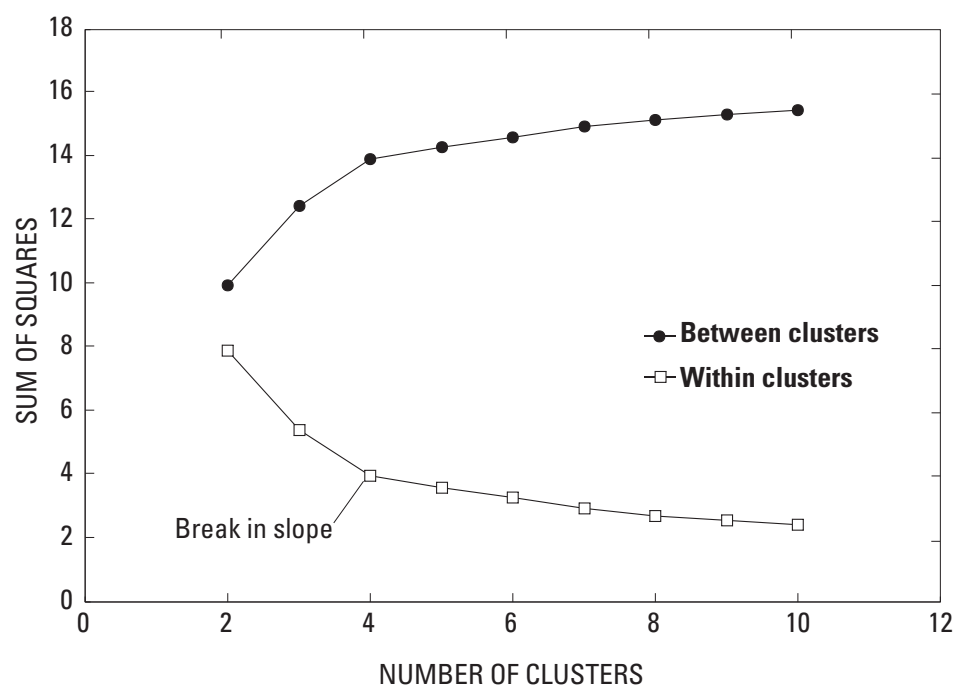

CLUSTER NUMBER

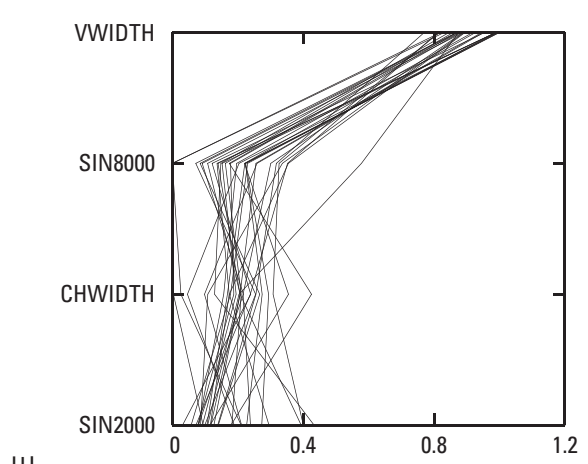

3

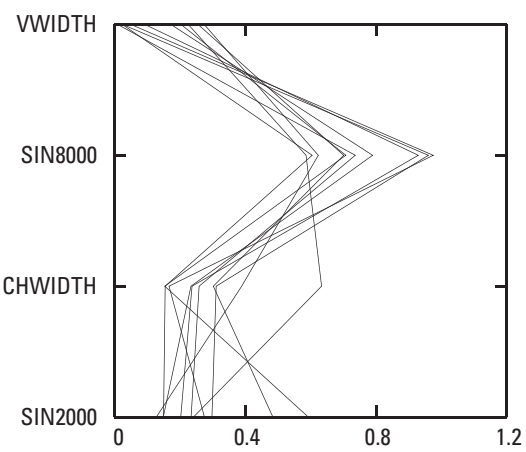

2

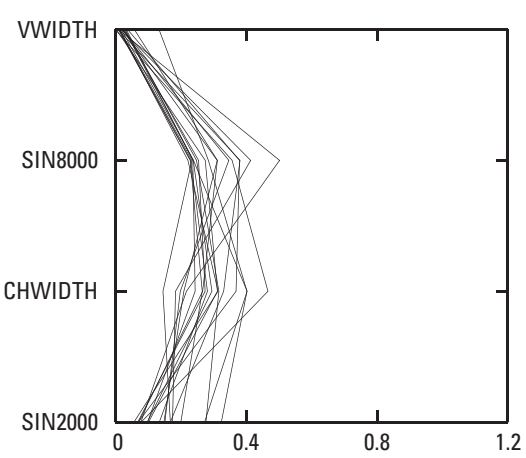

4

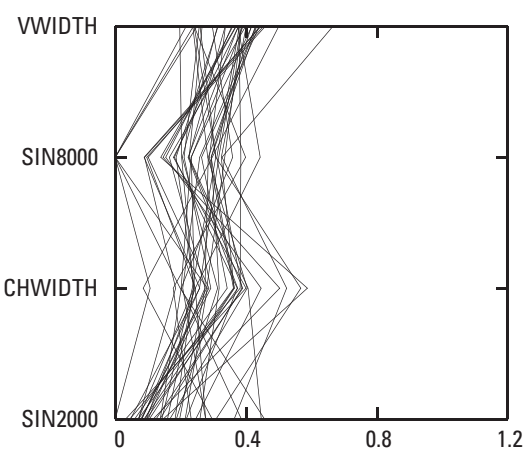

Figure 12. Changes in sum of square differences within and among clusters as number of clusters changes. A prominent break in slope exists at four clusters. Additionally seven clusters were explored in the classification process, although the change in information 4 to 10 clusters is gradual.

\section{STANDARDIZED VALUE OF THE VARIABLE RELATIVE TO THE MEAN}

\section{EXPLANATION}

VWIDTH Valley width

CHWIDTH Channel width

SIN2000 Channel sinuosity calculated over a 2,000 meter-ruler SIN8000 Channel sinuosity calculated over a 8,000 meter-ruler
Figure 13. Clustering results from the K-means procedure for four clusters. Cluster-parallel plots show standardized values of the variables (relative to mean) for each cluster. The variables are arranged generally from most to least affect from top to bottom. 
CLUSTER NUMBER

1

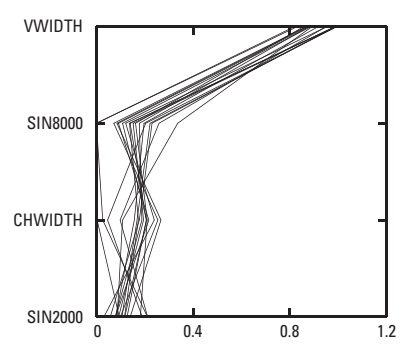

4

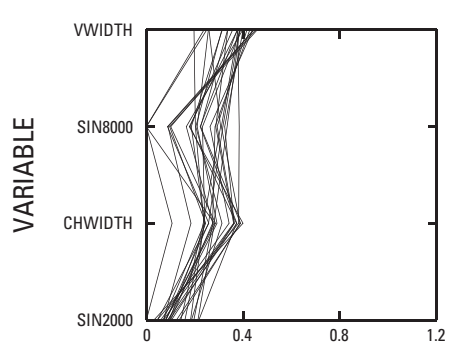

7

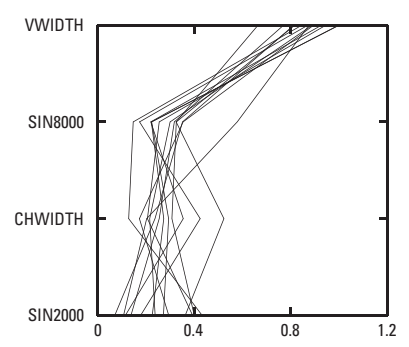

STANDARDIZED VALUE OF VARIABLE RELATIVE TO THE MEAN
2

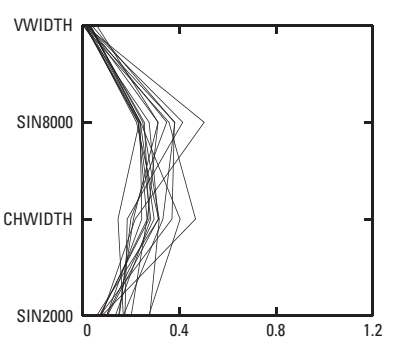

5

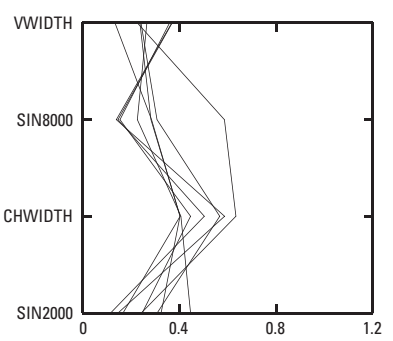

STANDARDIZED VALUE OF VARIABLE RELATIVE TO THE MEAN

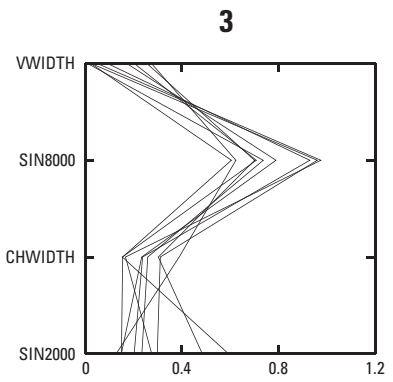

6

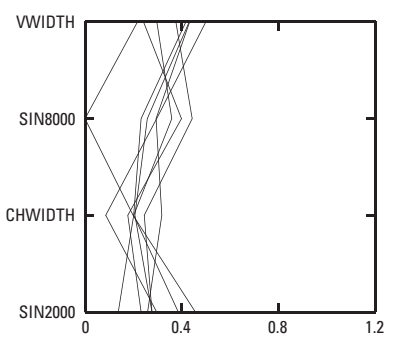

\section{EXPLANATION}

$\begin{array}{ll}\text { VWIDTH } & \text { Valley width } \\ \text { CHWIDTH } & \text { Channel width } \\ \text { SIN2000 } & \text { Channel sinuosity calculated over a } \mathbf{2 , 0 0 0} \text { meter-ruler } \\ \text { SIN8000 } & \text { Channel sinuosity calculated over a 8,000 meter-ruler }\end{array}$

Figure 14. Clustering results from the K-means procedure for seven clusters. Cluster-parallel plots show standardized values of the variables (relative to mean) for each cluster. The variables are arranged generally from most to least affect, from top to bottom.

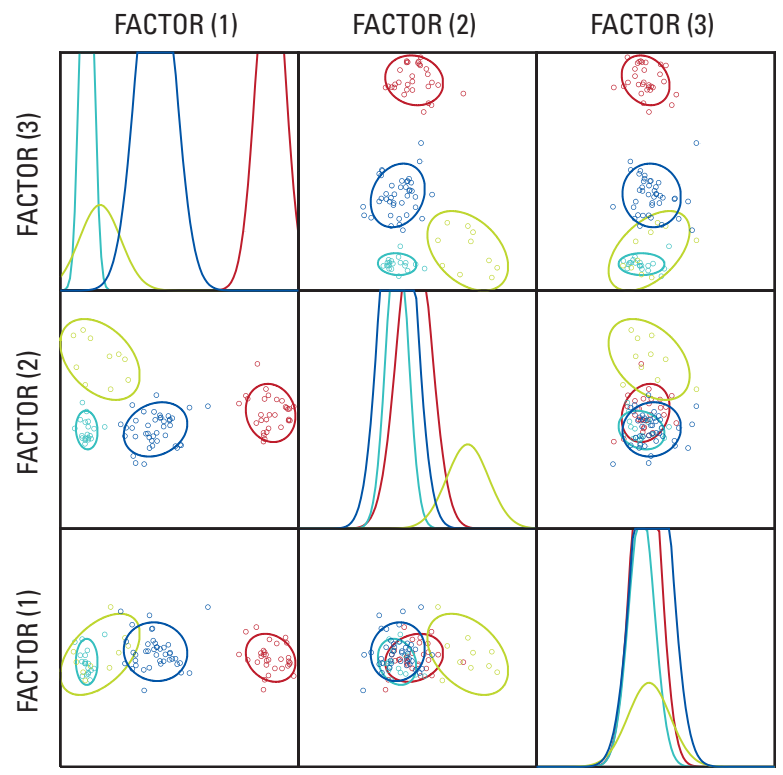

EXPLANATION
Cluster number
-1
-2
-3
-4

Figure 15. Canonical scores for the four-cluster classification. Ellipses show the groupings used for classification. 

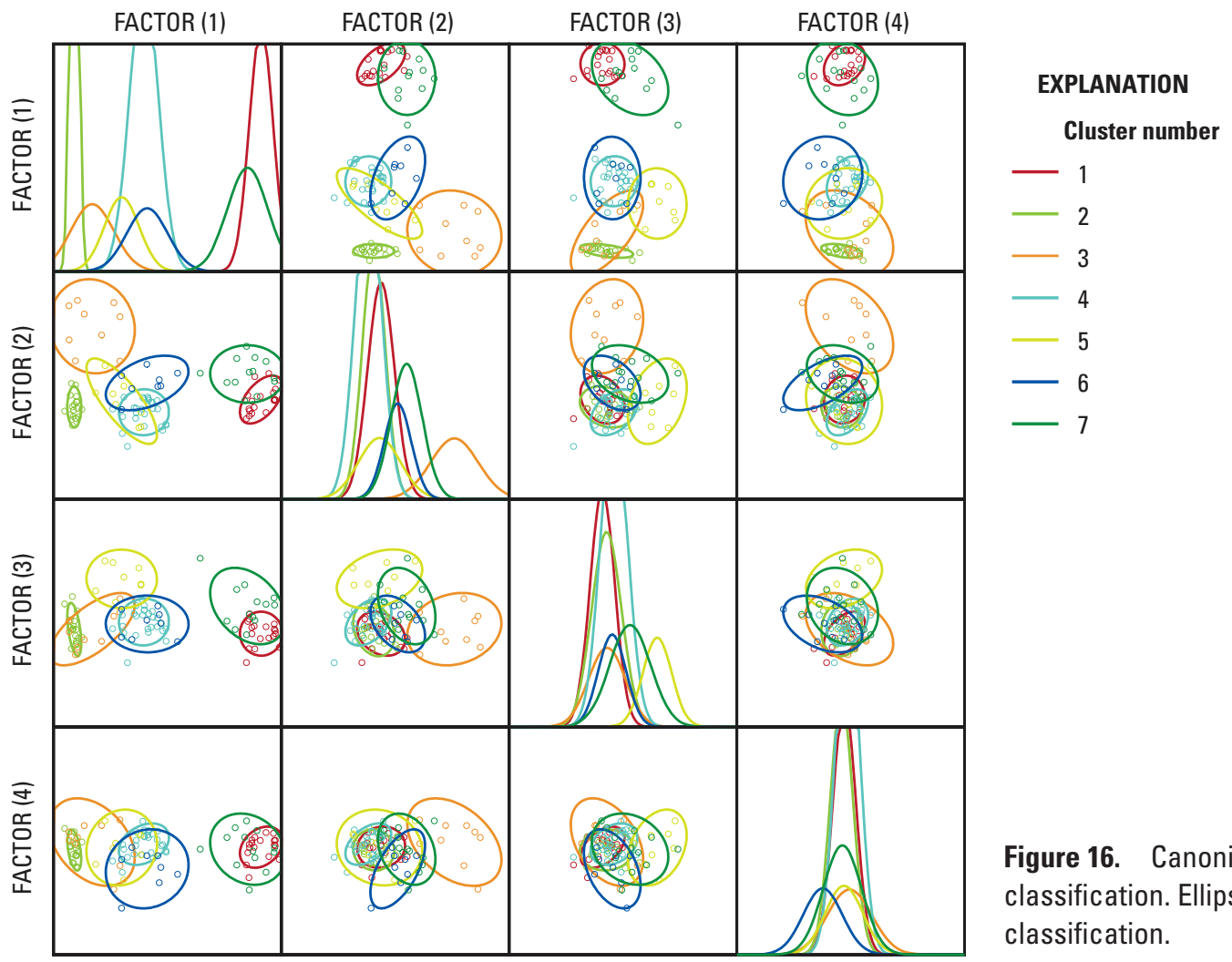

Figure 16. Canonical scores for the seven-cluster classification. Ellipses show the groupings used for classification.

Table 4. Result of jackknife validation of discriminant function classification of four- and seven-cluster classifications.

\begin{tabular}{|c|c|c|c|c|c|c|c|c|c|}
\hline \multirow{8}{*}{ Classified by jackknife } & \multicolumn{5}{|c|}{ Classification } & \multirow[b]{2}{*}{$\begin{array}{c}\text { Percent } \\
\text { correct }\end{array}$} & & & \\
\hline & Classification & 1 & 2 & 3 & 4 & & & & \\
\hline & \multicolumn{6}{|c|}{ Four-cluster class } & & & \\
\hline & 1 & 30 & 0 & 0 & 0 & 100 & & & \\
\hline & 2 & 0 & 19 & 0 & 0 & 100 & & & \\
\hline & 3 & 0 & 0 & 10 & 0 & 100 & & & \\
\hline & 4 & 1 & 0 & 0 & 40 & 98 & & & \\
\hline & \multirow[t]{2}{*}{ Total } & 31 & 19 & 10 & 40 & 99 & & & \\
\hline & & \multicolumn{7}{|c|}{ Classification } & \multirow[b]{2}{*}{$\begin{array}{l}\text { Percent } \\
\text { correct }\end{array}$} \\
\hline \multirow{10}{*}{ Classified by jackknife } & Classification & 1 & 2 & 3 & 4 & 5 & 6 & 7 & \\
\hline & \multicolumn{9}{|c|}{ Seven-cluster class } \\
\hline & 1 & 18 & 0 & 0 & 0 & 0 & 0 & 0 & 100 \\
\hline & 2 & 0 & 18 & 0 & 0 & 0 & 0 & 0 & 100 \\
\hline & 3 & 0 & 1 & 7 & 0 & 1 & 0 & 0 & 78 \\
\hline & 4 & 0 & 0 & 0 & 26 & 0 & 0 & 0 & 100 \\
\hline & 5 & 0 & 0 & 0 & 1 & 7 & 0 & 0 & 88 \\
\hline & 6 & 0 & 0 & 0 & 1 & 0 & 7 & 0 & 88 \\
\hline & 7 & 1 & 0 & 0 & 0 & 0 & 0 & 12 & 92 \\
\hline & Total & 19 & 19 & 7 & 28 & 8 & 7 & 12 & 95 \\
\hline
\end{tabular}


Table 5. Names and interpreted physical significance of clustered classes.

[NA, not available; LPR, Lower Platte River]

\begin{tabular}{|c|c|c|c|}
\hline Classification & $\begin{array}{l}\text { Dominant } \\
\text { relation to } \\
\text { four-cluster } \\
\text { (see table 4) }\end{array}$ & $\begin{array}{l}\text { Descriptive } \\
\text { name }\end{array}$ & Physical process interpretation \\
\hline & & & Four-cluster classification \\
\hline 1 & NA & $\begin{array}{l}\text { Wide valley, low } \\
\text { sinuosity }\end{array}$ & $\begin{array}{l}\text { This unit characterizes the LPR upstream from the Loup River confluence. Channel } \\
\text { width is variable and the } 8,000 \text {-meter sinuosity is low. The } 2,000 \text {-meter sinuosity } \\
\text { is somewhat higher indicating greater flow complexity at shorter scales. }\end{array}$ \\
\hline 2 & NA & $\begin{array}{l}\text { Narrow valley, low } \\
\text { sinuosity }\end{array}$ & $\begin{array}{l}\text { This unit occurs in the narrow valley of the Eastern Platte River Gorge (Joeckel and } \\
\text { Henebry, 2008). }\end{array}$ \\
\hline 3 & NA & $\begin{array}{l}\text { Narrow valley, } \\
\text { high sinuosity }\end{array}$ & $\begin{array}{l}\text { This unit occurs in the narrow valley of the Eastern Platte River Gorge (Joeckel and } \\
\text { Henebry, 2008). High sinuosity at 8,000-meter scale captures the valley-scale } \\
\text { bends. A few bends within the Elkhorn-Loup segment also are included. }\end{array}$ \\
\hline 1 & 1 & $\begin{array}{l}\text { Wide valley, low } \\
\text { sinuosity }\end{array}$ & $\begin{array}{l}\text { This unit characterizes the LPR upstream from the Loup River confluence. Channel } \\
\text { width is variable and the } 8,000 \text {-meter sinuosity is low. The } 2,000 \text {-meter sinuosity } \\
\text { is somewhat higher indicating greater flow complexity at shorter scales. }\end{array}$ \\
\hline 2 & 2 & $\begin{array}{l}\text { Narrow valley, low } \\
\text { sinuosity }\end{array}$ & $\begin{array}{l}\text { This unit occurs in the narrow valley of the Eastern Platte River Gorge (Joeckel and } \\
\text { Henebry, 2008). }\end{array}$ \\
\hline 3 & 3 & $\begin{array}{l}\text { Narrow valley, } \\
\text { high sinuosity }\end{array}$ & $\begin{array}{l}\text { This unit occurs in the narrow valley of the Eastern Platte River Gorge (Joeckel and } \\
\text { Henebry, 2008). High sinuosity at 8,000-meter scale captures the valley-scale } \\
\text { bends. A few bends within the Elkhorn-Loup segment also are included. }\end{array}$ \\
\hline 4 & 4 & $\begin{array}{l}\text { Medium valley, } \\
\text { high channel } \\
\text { width, low } \\
\text { sinuosity }\end{array}$ & $\begin{array}{l}\text { This unit occurs in the Elkhorn-Loup segment, characterized by medium valley } \\
\text { width and low-medium sinuosities. }\end{array}$ \\
\hline 7 & 1 & $\begin{array}{l}\text { Wide valley, low } \\
\text { medium sinuos- } \\
\text { ity and channel } \\
\text { width }\end{array}$ & $\begin{array}{l}\text { This unit characterizes the LPR upstream from the Loup River confluence. Channel } \\
\text { width is slightly greater than unit } 1 \text { and the } 2,000 \text {-meter sinuosity also is slightly } \\
\text { higher than that of unit } 1 \text {, indicating reaches with somewhat greater flow com- } \\
\text { plexity at shorter scales. }\end{array}$ \\
\hline
\end{tabular}



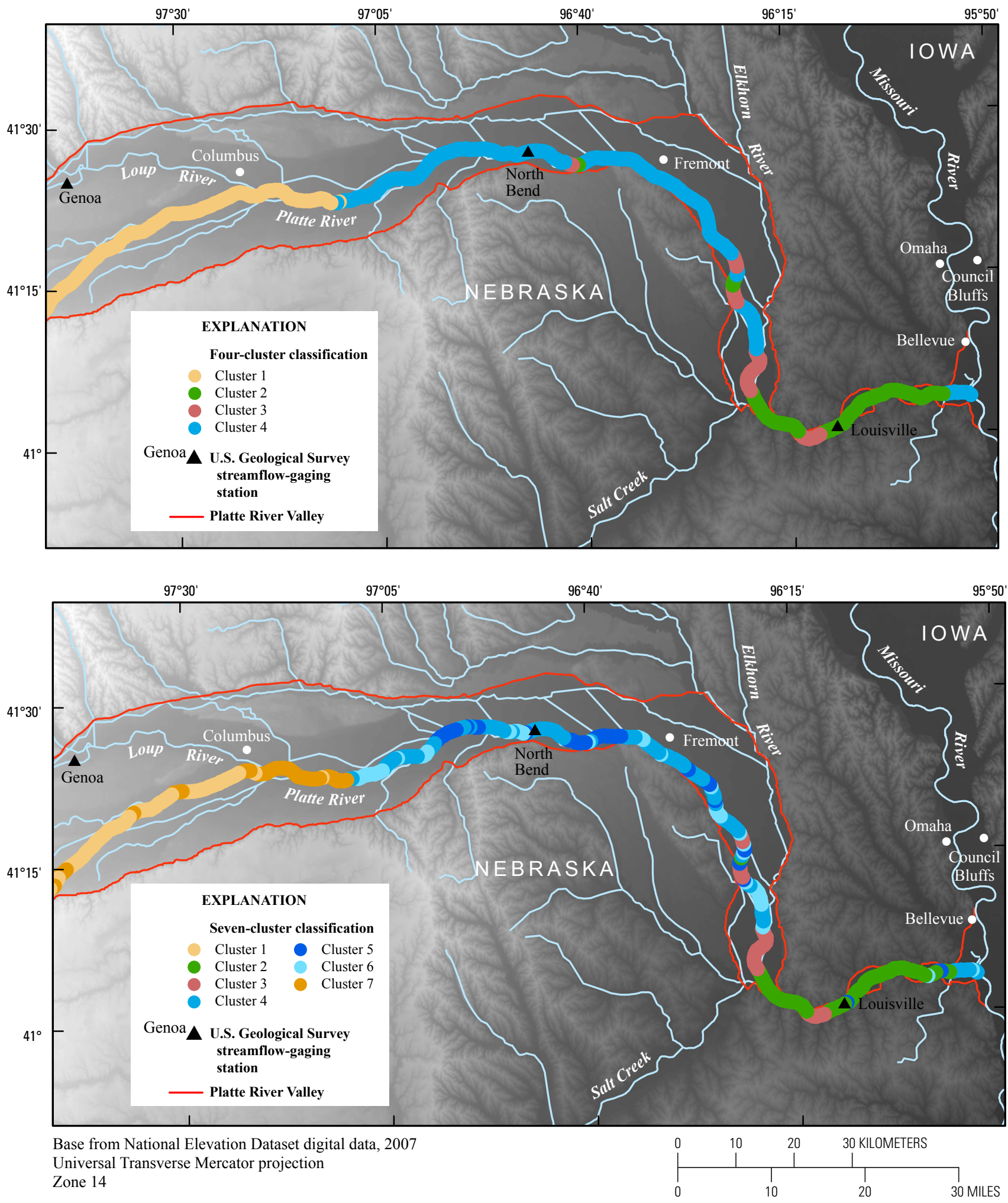

Figure 17. Examples of four- and seven-cluster classifications on the Lower Platte River. 


\section{Valley and Channel Width}

The Lower Platte River flows through a valley ranging from 1.1 to $26.9 \mathrm{~km}$ wide (fig. 7, table 6). The average valley width above the Loup River is $24.5 \mathrm{~km}$. The segment between the Loup and Elkhorn Rivers averages $11.8 \mathrm{~km}$, and the segment below the Elkhorn in the Eastern Platte River Gorge is the narrowest, ranging from 1.1 to $7.6 \mathrm{~km}$, with an average width of $4.8 \mathrm{~km}$.

Active channel width varies considerably along the entire Lower Platte ranging from $120 \mathrm{~m}$ to $1,358 \mathrm{~m}$ with a mean width of $485 \mathrm{~m}$ (fig. 7). The narrowest segment of the study area is upstream from the Loup junction with a mean width of $375 \mathrm{~m}$. The segment between the Loup and Elkhorn Rivers is the widest with channel widths ranging from 200 to $1,385 \mathrm{~m}$, with a mean width of $535 \mathrm{~m}$.

\section{Sinuosity}

Sinuosity has been shown to relate to channel curvature, flow separation, and hydraulic diversity (Barbour and others, 1999). Sinuosity ranges from 1.01 to 1.14 when measured at scales from 1,000 $\mathrm{m}$ to $16,000 \mathrm{~m}$ on the Lower Platte River (table 6). All values for sinuosity on the Platte River are fairly low and are indicative of a generally straight channel when measured along the active channel centerline. Sinuosity is highest at all scales in the reach downstream from the Elkhorn River (fig. 7, table 6). Sinuosity generally increases with scale on the Platte River.

\section{Braiding}

The number of channels counted by intersecting wet sand and deep water is used as a relative braiding index for reaches downstream from the Loup River. Upstream from the Loup River it was not possible to discriminate between dry sand and channel features because of the dry conditions in available imagery, so braiding index was not calculated. Based on the classification and enumeration method and the flow conditions at the time the imagery was collected, the Lower Platte River along its course has between 1 and 24 channels, with an average of 8.8 channels (fig. 7, table 6). The segment of the Platte River between the Loup and Elkhorn Rivers exhibits a higher average braiding index (9.3) than the segment downstream from the Elkhorn River (7.6).

\section{Statistical Classification}

In general, the classifications provided physically realistic and distinct classes for the 2006 channel (fig. 17). Valley width had the greatest affect in both classifications, indicating the large amount of variation in valley width from upstream to downstream. The next variable in the cluster analysis with the greatest affect was sinuosity at the $8,000-\mathrm{m}$ scale, followed by channel width and sinuosity at the 4,000-m scale. Although the K-means cluster analysis does not necessarily result in hierarchical nesting of clusters, the seven-cluster classes tend to fit within the four-cluster classes (table 5), and the sevencluster classes generally can be described as subunits of the four-cluster classes.

\section{Classification Assessment Based on In-Channel Dependent Variables}

The approach to classification was to select relatively independent geomorphic variables and determine how they naturally clustered. This classification can be explored further, in part, by assessing how well dependent variables relate to the geomorphically defined classes. We identified percent area of deep water, braiding index, percent area of dry sand, and percent area of dark vegetation as indicative dependent variables (figs. 18-19).

In the four-cluster classification, cluster 1 is preferentially mapped in the Lower Platte River upstream from the Loup River. Imagery used to classify the Lower Platte River documented low to no flow water conditions (fig. 3, table 1). Cluster 1 is characterized by low area of deep water, low braiding index (because it was not possible to discern channels upstream from the Loup River, braiding index was not calculated for much of cluster 1), and high area of dry sand and dark vegetation (fig. 18). The co-occurrence of large areas of dry sand and dark vegetation in cluster 1 emphasizes that cluster 1 can have stable islands and abundant emergent sandbars. Clusters 2 and 3 mostly are in the Eastern Platte River Gorge with narrow valley width and relatively high sinuosity. These clusters have relatively large areas of deep water and high braiding indices. They both have relatively small areas of dry sand, but cluster 2 (the low-sinuosity cluster in the Gorge) has small areas of stable, dark-vegetated islands, whereas cluster 3 has substantially greater areas of vegetated islands. Cluster 2 contained 81 percent of Platte River tern and plover nests from 2006 to 2008, whereas cluster 3 contained 11 percent. Cluster 4 of the four-cluster classification has moderate values of braiding index, dry sand, and dark vegetation with areas of deep water that are similar to cluster 1 and substantially lower than clusters 2 and 3.

The seven-cluster classification essentially subdivides cluster 1 of the four-cluster classification into clusters with relatively low sinuosity and channel width (cluster 1) and somewhat higher sinuosity and channel width (cluster 7, fig. 18). Clusters 1 and 7 have similar amounts of deep water. Because cluster 1 is almost entirely within the segment upstream from the Loup River, braiding index was not calculated; braiding index of cluster 7 is low for all samples indicating difficulty with identifying channel in dewatered reaches. Clusters 2 and 3 for the seven-cluster classification map almost entirely into the same clusters in the four-cluster classification and have the same distributions of deep water, braiding index, dry sand, and dark vegetation. Cluster 4 of the of the four-cluster 
Table 6. Lower Platte River geomorphic attributes summarized by hydrologic segment.

$[--$, no data $]$

\begin{tabular}{|c|c|c|c|c|}
\hline & $\begin{array}{c}\text { Platte River } \\
\text { above } \\
\text { Loup River }\end{array}$ & $\begin{array}{l}\text { Platte River } \\
\text { between } \\
\text { Loup and } \\
\text { Elkhorn Rivers }\end{array}$ & $\begin{array}{l}\text { Platte River } \\
\text { downstream } \\
\text { from the } \\
\text { Elkhorn River }\end{array}$ & $\begin{array}{c}\text { Entire } \\
\text { Platte River } \\
\text { study reach }\end{array}$ \\
\hline Beginning kilometer & 167 & 52 & 0 & 0 \\
\hline Ending kilometer & 216 & 167 & 52 & 216 \\
\hline Total kilometers & 49 & 115 & 52 & 216 \\
\hline \multicolumn{5}{|c|}{ Valley width, in kilometers } \\
\hline Maximum valley width & 26.9 & 24.0 & 7.6 & 26.9 \\
\hline Minimum valley width & 22.2 & 5.3 & 1.1 & 1.1 \\
\hline Average valley width & 24.5 & 11.8 & 4.8 & 12.9 \\
\hline \multicolumn{5}{|c|}{ Channel width, in meters } \\
\hline $\begin{array}{l}\text { Maximum channel } \\
\text { width }\end{array}$ & 660 & 1,385 & 847 & 1,385 \\
\hline $\begin{array}{l}\text { Minimum channel } \\
\text { width }\end{array}$ & 120 & 200 & 185 & 120 \\
\hline Average channel width & 375 & 535 & 470 & 485 \\
\hline \multicolumn{5}{|c|}{ Sinuosity } \\
\hline 1,000 -meter sinuosity & 1.01 & 1.02 & 1.02 & 1.02 \\
\hline 2,000-meter sinuosity & 1.02 & 1.02 & 1.03 & 1.02 \\
\hline 4,000-meter sinuosity & 1.03 & 1.04 & 1.05 & 1.04 \\
\hline 8,000-meter sinuosity & 1.04 & 1.06 & 1.08 & 1.06 \\
\hline 16,000 -meter sinuosity & 1.04 & 1.08 & 1.14 & 1.08 \\
\hline \multicolumn{5}{|c|}{ Braid index } \\
\hline Maximum braid index & -- & 24 & 20 & 24 \\
\hline Minimum braid index & -- & 1 & 1 & 1 \\
\hline Average braid index & -- & 9.30 & 7.6 & 8.80 \\
\hline
\end{tabular}

classification splits into clusters 4,5 , and 6 in the seven-cluster classification. Cluster 4 has moderate values of deep water, braiding index, dry sand, and dark vegetation. Cluster 5 stands out in having low area of deep water, substantially higher braiding index, and relatively low areas of dry sand. Among the three related clusters, cluster 5 has the highest area of dark vegetation, which probably is explained by the relatively high channel width that allows for survival of stable islands. Cluster 6 is remarkable for moderate levels of deep water, braiding index, and dry sand; cluster 6 has low areas of dark vegetation coincident with narrow channel widths.

\section{Classification Assessment Based on Nesting Locations}

To assess the utility of the classification for predicting nesting habitat, least tern and piping plover nest locations for 2006-08 mapped by Nebraska Game and Parks Commission (Joel Jorgenson, unpub. data, Nebraska Game and Parks Commission, 2009; Brown and Jorgenson, 2008) were spatially joined with classified reaches. Tern and plover nests primarily fell in reaches belonging to clusters 2 and 4 of the four-cluster classification and clusters 2 and 6 of the seven-cluster classification (table 7). Contingency table analysis shows that the distribution of nests is significantly nonindependent of reach class for both class systems (Chi-square, $\mathrm{P}<0.01$ ). Cluster 2 of the four-cluster classification primarily is located downstream from where the Elkhorn and Salt Rivers enter the Platte River 

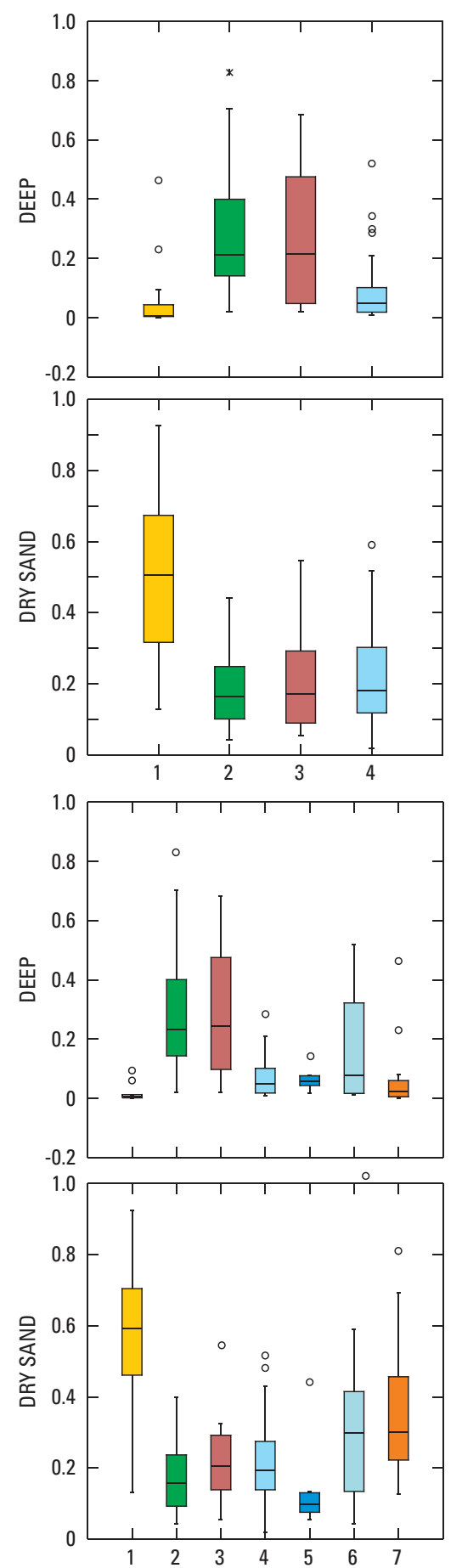
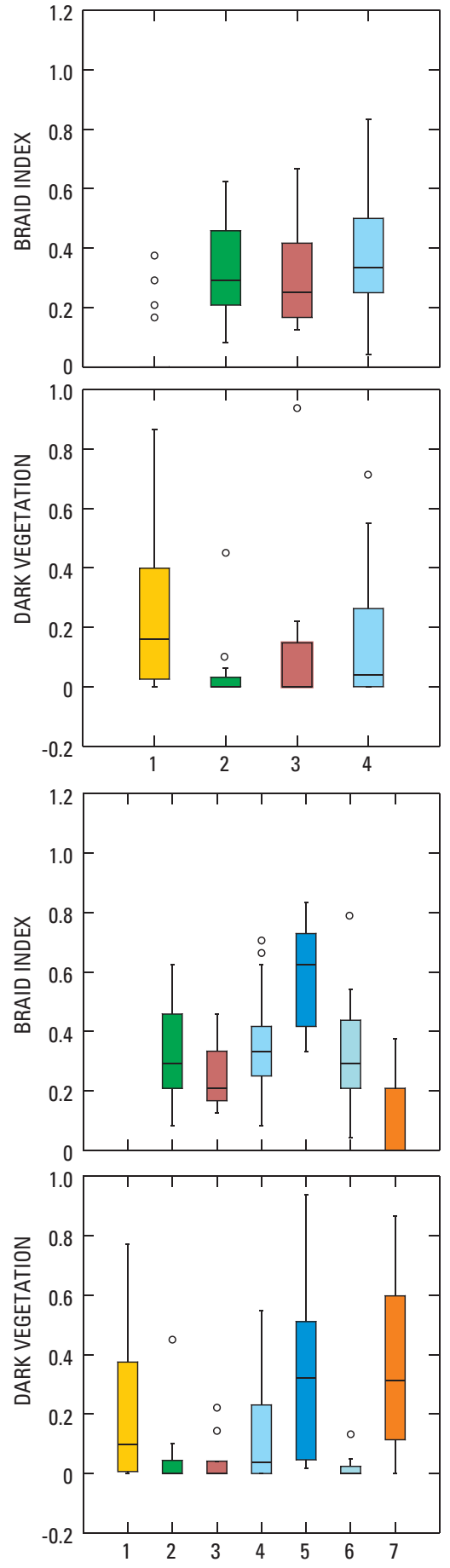

EXPLANATION

○ — VALUE GREATER THAN 1.5 TIMES THE INTERQUARTILE RANGE ABOVE BOX

LARGEST VALUE WITHIN 1.5 TIMES THE INTEROUARTILE RANGE ABOVE BOX

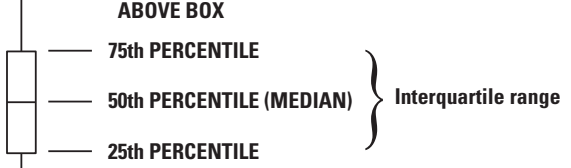

1 SMALLEST VALUE WITHIN 1.5 TIMES THE INTEROUARTILE RANGE BELOW BOX

○ — VALUE GREATER THAN 1.5 TIMES THE INTEROUARTILE RANGE BELOW BOX

Four-cluster classification

Cluster 1

Cluster 2

Cluster 3

Cluster 4

Seven-cluster classification

Cluster 1

Cluster 2

Cluster 3

Cluster 4

Cluster 5

Cluster 6

Cluster 7

\section{CLASSIFICATION CLUSTER NUMBER}

Figure 18. Response variables by four- and seven-cluster classifications. 


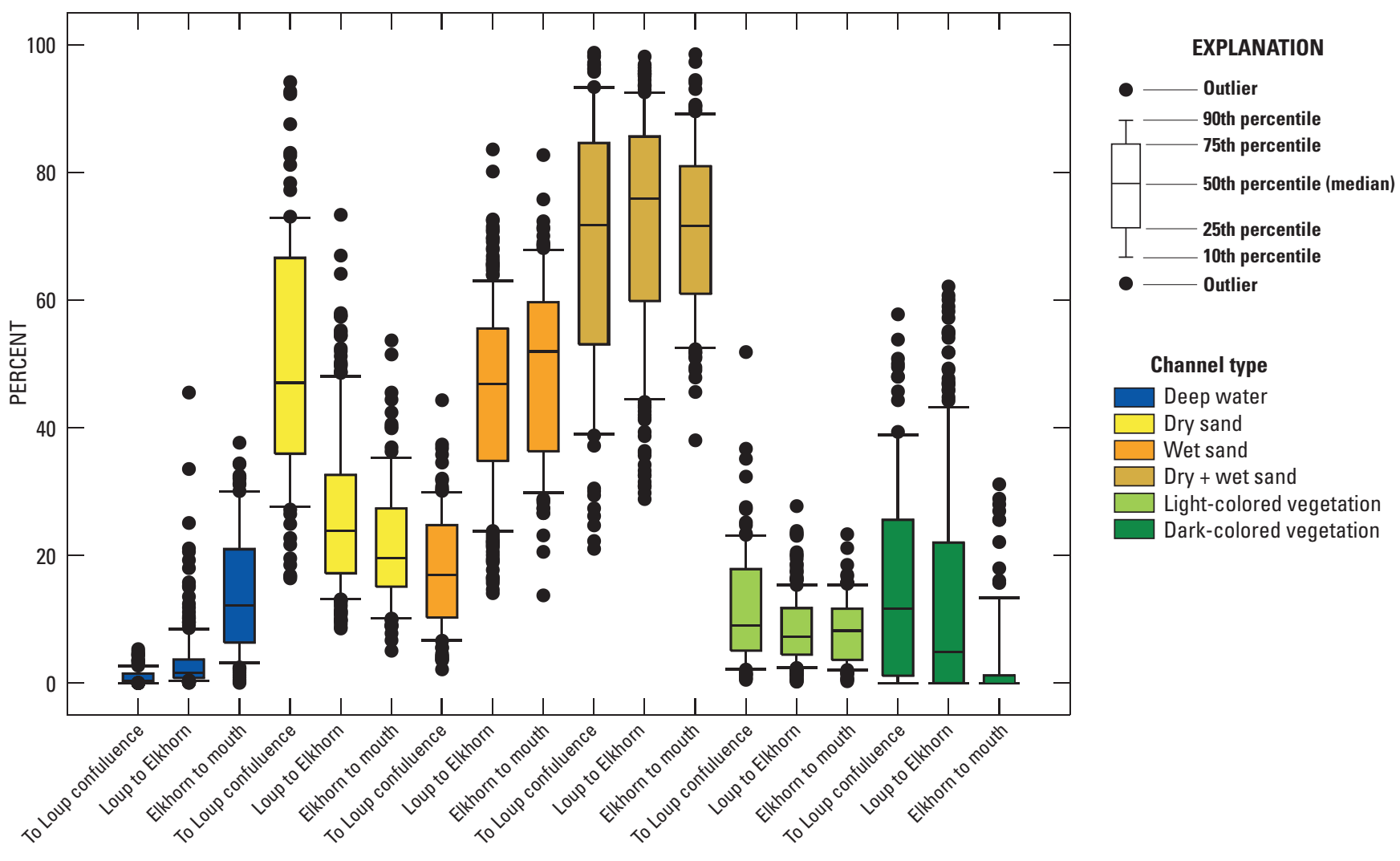

PLATTE RIVER STUDY REACHES

Figure 19. Percent channel type from supervised imagery classification, by reach, for the Lower Platte River.

Table 7. Tern and Plover nest locations and selectivity coefficients by cluster type.

\begin{tabular}{|c|c|c|c|c|c|}
\hline Classification & $\begin{array}{l}\text { Number of } \\
\text { reaches }\end{array}$ & $\begin{array}{l}\text { Percentage of } \\
\text { total reaches }\end{array}$ & $\begin{array}{l}\text { Number of tern } \\
\text { or plover Nests }\end{array}$ & $\begin{array}{l}\text { Percentage of total } \\
\text { tern or plover nests }\end{array}$ & $\begin{array}{l}\text { Selectivity } \\
\text { coefficient }\end{array}$ \\
\hline \multicolumn{6}{|c|}{ Four-cluster } \\
\hline 1 & 127 & 29 & 9 & 3 & -1.00 \\
\hline 2 & 78 & 18 & 113 & 49 & .55 \\
\hline 3 & 40 & 9 & 36 & 14 & .08 \\
\hline 4 & 189 & 44 & 89 & 34 & -.22 \\
\hline Total & 434 & & 265 & & \\
\hline \multicolumn{6}{|c|}{ Seven-cluster } \\
\hline 1 & 80 & 18 & 4 & 2 & -1.00 \\
\hline 2 & 71 & 16 & 129 & 49 & .54 \\
\hline 3 & 32 & 7 & 36 & 14 & .37 \\
\hline 4 & 106 & 24 & 36 & 14 & -.77 \\
\hline 5 & 47 & 11 & 2 & 1 & -.82 \\
\hline 6 & 49 & 11 & 53 & 20 & .38 \\
\hline 7 & 49 & 11 & 5 & 2 & -1.00 \\
\hline Total & 434 & & 265 & & \\
\hline
\end{tabular}


in the Eastern Platte River Gorge. Cluster 2 makes up only 18 percent of the reaches in the Lower Platte River, yet supported 49 percent of the Tern and Plover nests in 2006-08. Cluster 4 in the four-cluster classification, on the mainstem Platte River primarily between the Loup and Elkhorn Rivers, had 34 percent of the nests, and comprises 44 percent of the reaches in the Lower Platte River (table 7). For the seven-cluster classification 49 percent of the nests fell within cluster 2, which represents 16 percent of the reaches in the Lower Platte River and occurs primarily downstream from where the Elkhorn and Salt Rivers enter the Platte River (table 7). Reaches with low percentages of nest locations such as clusters 1,5 , and 7 in the 7-cluster classification also had high percentages of dark vegetation (table 7 , fig. 18).

Selectivity coefficients (table 7) indicate that among the 4-cluster reaches, cluster 2 reaches were selected in greater proportion compared to its abundance. Although 34 percent of the tern and plover nests were located in cluster 4 , this class comprises 44 percent of the available reaches, and the selectivity coefficient of -0.22 indicates relative avoidance. Among the seven-cluster reaches, clusters 2, 3, and 6 were selected, whereas clusters $1,4,5$, and 7 were avoided. Selectivity coefficients support the importance of the Eastern Platte River Gorge and relatively high sinuosity reaches of the Loup-Elkhorn segment for nesting.

\section{Discussion}

Given the general availability of sand in the Lower Platte River, the extent and persistence of emergent sandbars on the Lower Platte River likely is limited by discharges that are capable of transporting sand and destabilizing vegetated bars. The capacity for the channel to develop necessary shear stresses will be determined by the flow regime in the segment and mediated by geomorphic controls on flow concentration. An a priori hierarchical classification for the Lower Platte River, therefore, would place the hydrologic segmentation of the Lower Platte River in the first tier, recognizing the potential for affects on the flow regime from the mainstem upstream, the Loup and Elkhorn Rivers, and Salt Creek.

The classification presented here addresses the geomorphic mediation of flow regime and provides an indirect assessment of sandbar habitat potential for least terns and piping plovers. Suitability of classified river reaches for sandbar habitat must be inferred from understanding how the physical processes responsible for creating the geomorphic forms relate to physical processes that create and maintain habitat. Valley width and channel width act to constrict flow and, thereby, enhance sediment transport and bar building. Upstream from the Elkhorn River, valley width would rarely, if ever, constrain flood flows because of its breadth. Downstream from the Elkhorn River and Salt Creek, and especially in the Eastern Platte River Gorge, constriction of large floods could be expected to increase scour and reworking of bars, potentially resulting in greater persistence of bare sandbars for nesting. This reach made up 18 percent of the four-cluster classification and contained 49 percent of all tern and plover nests for 2006-08. Conversely, relatively wide channel segments (for example, cluster 5 in the seven-cluster classification) would minimize constriction for bankfull flows, and potentially allow for persistence of vegetated bars and islands. Cluster 5 in the seven-cluster classification contained 11 percent of the reaches and 1 percent of all tern and plover nests from 2006-08.

Confined width also was implicated as a dominant control on channel morphology in an adjacent upstream segment of the Platte River (Fotherby, 2009). Fotherby (2009) classified a segment of the Central Platte River into braided and anastomosing reaches. At confined widths less than $600 \mathrm{~m}$, fully braided channel configuration was maintained, but at widths greater than $600 \mathrm{~m}$, vegetated islands and an anastomosed channel pattern dominated. The inverse relation between valley width and braiding index in the data (fig. 7) confirms this association.

At the scales measured in this study, channel sinuosity is an indirect measure of flow complexity associated with channel curvature. Compared to a straight channel with similar width, flow regime, and sediment supply, a sinuous channel will be characterized by greater concentrations of shear stress associated with convergence of flow on the outsides of bends and stronger secondary currents. Secondary currents may lead, in turn, to maintenance of point and lateral sandbars. The relative role of sinuous channels in maintaining emergent sandbar habitat in the Lower Platte River may be enhanced to the extent that flow regulation reduces frequency or duration of flows that would be capable of transporting sand and maintaining bars in straight, braided segments. Under flow-regulated conditions, sandbars in straight reaches may have a greater tendency to become stabilized by vegetation than those in sinuous reaches.

Implications for tern and plover habitat also can be inferred from associated in-channel characteristics. For example, reaches with higher densities of stable, vegetated bars are unlikely to provide large areas of bare sandbars suitable for nesting. Reaches that have higher densities of dark vegetated bars include clusters 5 and 7 (fig. 18), which combined had few tern and plover nests in 2006-08 (3 percent). Cluster 5 is notable for having low areas of dry sand as well. Reaches characterized by more area mapped as deep channel probably are less likely to support large areas of emergent sandbars, although as noted above, they may be associated with high sinuosity and sandbar persistence. Reaches with a relatively high braiding index but lower percentages of dark vegetation, such as cluster 6, also are more likely to have more emergent sandbars than other clusters. This cluster had a quarter of the nests (20 percent) mapped in 2006-08 (table 7).

Because a narrow valley and high sinuosity will enhance sediment transport and contribute to bar instability, the Eastern Platte River Gorge downstream from the Elkhorn River would be expected to have persistent sandbars, although the narrow valley width would limit their areal extent. Under conditions 
of declining peak flows, this segment of the river may provide the most persistent sandbar habitat. Less than one-half (49 percent) of the tern and plover nests in the Lower Platte River were mapped as cluster 2 (in the four-cluster classification) in the Eastern Platte River Gorge (table 7).

Daily fluctuations in discharge (fig. 1, table 1) complicate mapping of sandbars from available remotely sensed imagery and, thereby, present a substantial challenge to river classification and habitat assessment on the Lower Platte River. When flows fluctuate rapidly over the course of a single day, the timing of aerial photography can change what is identified as channel or sandbar. For example, in the 2006 imagery, reaches of the Platte River upstream from the Loup are nearly dewatered in some photographs in the NAIP imagery, and a high proportion of the channel was mapped as dry sand. It is likely that much of this sand is not available as habitat to nesting least terns and piping plovers over the course of their nesting period. Therefore, consideration of fluctuations in river discharge and timing of aerial photography is crucial when assessing the distribution of available sandbar habitat on a river.

Classification of the Lower Platte River could be improved with hydrologically consistent aerial photography or other remotely sensed imagery of sufficient resolution. To accomplish this, imagery would have to be acquired while major discharges and withdrawals to the Lower Platte River were held constant. Ideally, flows within each segment would be at the same flow exceedance, and the flow would be appropriate for assessing nesting habitat. Timing imagery acquisition for these conditions would allow for sandbar habitat to be uniformly identified and mapped on the Lower Platte River in a way similar to classifications established for the Missouri River below Gavins Point Dam (Elliott and Jacobson, 2006).

Identification of the use of sandbar habitat availability on the Platte River may require finer-resolution data than that available from remotely sensed images. Nest habitat data on the Platte River indicate that bar elevation relative to water surface may be an important factor in predicting nest sites (Ziewitz and others, 1992). Given the daily fluctuations in discharge on the Platte River, measurements of emergent sandbar habitat may require elevation data from airborne Light Detection and Ranging (LIDAR) measurements or finer-scale field survey measurements.

\section{Summary}

Geomorphic attributes collected from aerial photography were used to develop a classification of the downstream-most $220-\mathrm{km}$ of the Platte River in Nebraska. The classified river segments include the hydrologically distinct reaches of the Platte River 50-km upstream from the Loup River, between the Loup and Elkhorn Rivers, between the Elkhorn River and Salt Creek, and downstream from Salt Creek. An address system with 500-m spacing was developed for collection of geomorphic attributes.

The multiscale classification includes four-cluster and seven-cluster classifications that characterize the Lower Platte River channel using active channel width, valley width, and sinuosity as variables. Results indicate that the variation in valley width is an important variable from upstream to downstream on the Lower Platte River. The classification was validated using dependent geomorphic and vegetation variables derived from a supervised classification of 2006 NAIP orthophotography. These variables included the percent area of deep water, dry sand, dark vegetation, and braiding index. Validation of the classification with tern and plover nesting data for 2006-08 identified relative selection of cluster 2 reaches among the four-cluster classification, and relative selection of clusters 2, 3, and 6 reaches from the seven-cluster classification for nesting.

A direct inventory of emergent sandbar habitat at a constant flow exceedance during nesting season would be preferred for tern and plover nesting habitat assessments. This was not possible using existing aerial photography because of variations in hydrologic conditions within photographic datasets. Nonetheless, validation of the geomorphic classification indicates that broad-scale geomorphic features are useful for classifying the nesting potential of emergent sandbar habitats.

\section{Acknowledgments}

We thank Jeff Runge with the U.S. Fish and Wildlife Service for providing support for this project. Jeff and Joel Jorgenson, Nebraska Game and Parks Commission, provided data on tern and plover nesting on the Lower Platte River. Two critical reviews greatly improved this report.

\section{References Cited}

Barbour, M.T., Gerritsen, J., Snyder, B.D., and Stribling, J.B., 1999, Rapid bioassessment protocols for use in streams and wadeable rivers - Periphyton, benthic macroinvertebrates and fish: U.S. Environmental Protection Agency, Office of Water EPA 841-B-99-002, 339 p.

Brown, M.B., and Jorgenson, J.G., 2008, 2008 Interior least tern and piping plover monitoring, research, management, and outreach report for the Lower Platte River, Nebraska: Joint report on the Tern and Plover Conservation Partnership and the Nebraska Game and Parks Commission, p. $1-60$. 
Elliott, C.M., and Jacobson, R.B., 2006, Geomorphic classification and assessment of channel dynamics in the Missouri National Recreational River, South Dakota and Nebraska: U.S. Geological Survey Scientific Investigations Report 2006-5313, 66 p.

Fotherby, L.M., 2009, Valley confinement as a factor of braided river pattern for the Platte River: Geomorphology, v. 103 , no. 4 , p. $562-576$.

Frissell, C.A., Liss, W.J., Warren, C.E., and Hurley, M.D., 1986, A hierarchical framework for stream habitat classification-Viewing streams in a watershed context: Environmental Management, v. 10, no. 2, p. 199-214.

Hadley, R.F., Karlinger, M.R., Burns, A.W., and Eschner, T.R., 1987, Water development and associated hydrologic changes in the Platte River, Nebraska, U.S.A.: Regulated Rivers: Research and Management, v. 1, p. 331-341.

Higgins, J.V., Bryer, M.T., Khoury, M.L., and Fitzhugh, T.W., 2005, A freshwater classification approach for biodiversity and classification planning: Conservation Biology, v. 19, p. 432.

Hill, T., and Lewicki, P., 2006, Statistics-Methods and applications: Tusla, Oklahoma, StatSoft, Inc., 831 p.

Joeckel, R.M., and Henebry, G.M., 2008, Channel and island change in the Lower Platte River, eastern Nebraska, USA: 1855-2005: Geomorphology, v. 102, p. 407-418.

Johnson, W.C., 1994, Woodland expansions in the Platte River, Nebraska: Patterns and causes: Ecological Monographs, v. 64, no. 1, p. 45-84.

Keaton, J.N., Messinger, T., and Doheny, E., 2005, Development and analysis of regional curves for streams in the nonurban valley and ridge province, Maryland, Virginia, and West Virginia: U.S. Geological Survey Scientific Investigations Report 2005-5076, 116 p.

Kirsch, E.M., 1996, Habitat selection and productivity of Least Terns on the Lower Platte River, Nebraska: Wildlife Monographs, v. 132, p. 3-48.

Kondolf, G.M., Montogomery, D.M., Piégay, H., and Schmitt, L., 2003, Geomorphic classification of rivers and streams, in Kondolf, G.M., and Piégay, H., eds., Tools in fluvial geomorphology: Chichester, England, John Wiley and Sons, p. 171-204.

Lingle, G.R., 1993, Nest success and flow relationships on the Central Platte River, in Higgins, K.F., and Brashier, M.R., eds., The Missouri River and Its Tributaries: Piping Plover and Least Term Symposium: Brookings, South Dakota, South Dakota State University, p. 69-72.
Lott, C.A., 2006, Distribution and abundance of the interior population of the Least Tern (Sterna antillarum), 2005: U.S. Army Corps of Engineers Engineer Research and Development Center ERDC/EL TR-06-13, 100 p.

Manly, B.F.J., McDonald, L.L., Thomas, D.L., McDonald, T.L., and Erickson, W.P., 2002, Resource selection by animals - Statistical design and analysis for field studies (2nd ed.): Dordrecht, the Netherlands, Kluwer Academic Publishers, $221 \mathrm{p}$.

Murphy, P.J., Randle, T.J., Fotherby, L.M., and Daraio, J.A., 2004, The Platte River channel: history and restoration: U.S. Department of the Interior, Bureau of Reclamation, $310 \mathrm{p}$.

National Research Council, 2005, Endangered and threatened species of the Platte River: Washington D.C., The National Academies Press, 299 p.

Parham, J.E., 2007, Hydrologic analysis of the Lower Platte River from 1954-2004, with special emphasis on habitats of the endangered least tern, piping plover, and pallid sturgeon: Nebraska Game and Parks Commission, 186 p.

Piégay, H., and Schumm, S.A., 2003, Systems approach in fluvial geomorphology, in Kondolf, G.M., and Piégay, H., eds., Tools in fluvial geomorphology: Chichester, England, John Wiley and Sons, p. 105-135.

Rabeni, C.F., and Sowa, S.P., 2002, A landscape approach to managing the biota of streams and rivers, in Liu, J., and Taylor, W., eds., Integrating landscape ecology into natural resource management: Cambridge, Cambridge University Press, p. 114-142.

Randle, T.J., and Samad, M.A., 2003, Platte River flow and sediment transport between North Platte and Grand Island, Nebraska (1895-1999): U.S. Department of the Interior, Bureau of Reclamation, $83 \mathrm{p}$.

Schumm, S.A., and Lichty, R.W., 1963, Time, space, and causality in geomorphology: American Journal of Science, v. 263, p. 110-119.

Sidle, J.G., Carlson, D.E., Kirsch, E.M., and Dinan, J.J., 1992, Flooding: Mortality and habitat renewal for least terns and piping plovers: Colonial Waterbirds, v. 15, no. 1, p. 132-136.

Simons and Associates Inc., 2000, Physical history of the Platte River in Nebraska: Focusing upon flow, sediment transport, geomorphology, and vegetation: Prepared for U.S. Department of Interior, Platte River EIS Office, 195 p.

Sowa, S.P., Diamond, D.D., Abbitt, R., Annis, G.M., Gordon, T., Morey, M.E., Sorensen, G.R., and True, D., 2005, A GAP analysis for riverine ecosystems of Missouri: U.S. Department of Interior, U.S. Geological Survey, Missouri Resource Assessment Partnership, 237 p. 
U.S. Fish and Wildlife Service, 2006, Biological opinion on the Platte River recovery implementation program: U.S. Fish and Wildlife Service, $330 \mathrm{p}$.

Wilkinson, L., Engelman, L., Corter, J., and Coward, M., 2004, Cluster analysis: Statistics I: Richmond, California, Systat Inc., 57-91 p.

Williams, G.P., 1978, The case of the shrinking channels-The North Platte and Platte Rivers in Nebraska: U.S. Geological Survey Circular 781, 48 p.

Ziewitz, J.W., Sidle, J.G., and Dinan, J.J., 1992, Habitat conservation for nesting least terns and piping plovers on the Platte River, Nebraska: The Prairie Naturalist, v. 24, no. 1, p. $1-20$. 
Publishing support provided by: Rolla Publishing Service Center

For more information concerning this publication, contact: Director, USGS Columbia Environmental Research Center 4200 New Haven Road

Columbia, MO 65201

(573) 875-5399

Or visit the Columbia Environmental Research Center Web site at: http://www.cerc.usgs.gov/ 



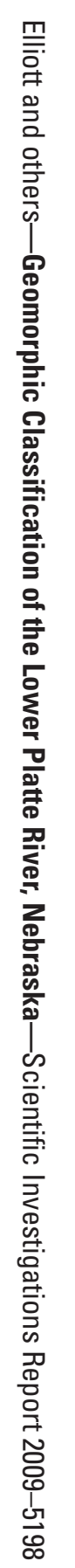

